\title{
Anti-Cancer Activity of Human Gastrointestinal Bacteria
}

\author{
Sameer Quazi, \\ GenLab Biosolutions Private Limited, Bangalore, Karnataka, India. (560043)
}

\begin{abstract}
:
Malignant neoplasm is one of the most incurable diseases among inflammatory diseases. Researchers have been studying for decades to win over this lethal disease and provide the light of hope to humankind. The gastrointestinal bacteria of human hold a complex ecosystem and maintain homeostasis. One hundred trillion microbes are residing in the gastrointestinal tract of human. Disturbances in the microbiota of human's gastrointestinal tract can create immune response against inflammation and also can develop diseases , including cancer. The bacteria of the gastrointestinal tract of human, can secrete a variety of metabolites and bioproducts which aid in the preservation of homeostasis in the host and gut. During pathogenic dysbiosis, on the other hand, numerous microbiota subpopulations may increase and create excessive levels of toxins, which can cause inflammation and cancer. Furthermore, the immune system of host and the epithelium cell can be influenced by gut microbiota. Probiotics, which are bacteria that live in the gut, have been protected against tumor formation. Probiotics are now studied to see if they can help fight dysbiosis in cancer patients undergoing chemotherapy or radiotherapy because of their capacity to maintain gut homeostasis. Countless numbers of gut bacteria have demonstrated anti-cancer efficiency in cancer treatment, prevention, and boosting the efficiency of immunotherapy. The review article has briefly explained the anti-cancer immunity of gut microbes and their application in treating a variety of cancer. This review paper also highlights the pre-clinical studies of probiotics against cancer and the completed and ongoing clinical trials on cancers with the two most common and highly effective probiotics Lactobacillus and Bacillus spp.
\end{abstract}

\section{Keywords:}

Lactobacillus spp, Bacillus spp., Anti-cancer, Probiotics, Gastrointestinal, Dysbiosis.

\section{Highlights}

1. The five main phyla of human gastrointestinal bacteria are Firmicutes, Bacteriodes, Actinobacteria, Proteobacteria, and Fusobacteria.

2. Probiotics are known as good gastrointestinal bacteria.

3. Bifidobacterium spp and Lactobacillus are the two most utilized probiotics in the market against cancer.

4. Fecal Microbiota Transplantation may be considered as an alternative in the future.

5. Probiotics metabolite's are the key elements that fight with cancer. 


\section{Introduction:}

The gastrointestinal tract (GI tract) or gut is the most convoluted environment of the human body. It is composed of a wide range of intestinal microbiome. Several micro-organisms, including bacteria, fungi, archaea, have consisted in the human epithelial barrier. Among them, commensal bacteria is the most prevalent one residing along cells in the GI tract $[1,2]$. The high-throughput advancement in the sequencing technology has enabled the precise identification of gut microbiota diversity [3]. Firmicutes, Bacteroides, Actinobacteria, Proteobacteria, and Fusobacteria are five dominant bacterial class in the human gut system [4]. Since development, the human gut microbial profile has remained constant throughout life and provides a unique "signature" for everyone with critical activities related to immune systems [4]. The structure of the microbiome and its generated metabolites impact a surprising number of local and systemic body functions. This involves energy production, dietary component metabolism, vitamin synthesis, and the control of immunological responses, behavior, and mood.

Dysbiosis, or disturbances in microbial populations, is being associated to distinct disorders, including diabetes, depression, obesity, inflammatory bowel disease, autism, and colorectal cancer [5-11]. The correlation that links the GI tract's bacteria and immune system has garnered considerable interest as it becomes exceeding apparent that inflammatory processes underpin various diseases. The complex relation between gut bacteria and host's immune system is very interesting. The ability of immune system to respond to infectious non-communicable diseases is influenced not merely by the presence or absence of bacterial species, but also through the by products produced and changed by microbes.[12] Furthermore, new findings have emphasized their critical role in response to various cancer therapies [13], implying that managing gut bacteria can improvise the efficiency of different neoplasm treatments by reducing cytotoxic activity and increasing anticancer activity. Over the last couple of years, the invention of metagenomics and by integrating next-generation sequencing (NGS) with 16Sr RNA sequencing analysis, metagenomics was able to distinguish both the variant and abundance of the gut bacteria [14].The combination of advances in metagenomics, transcriptomics, and metabolomics has allowed for the description of the effect of bacterial species on human $[15,16]$. This marks a transition from illustrative microbiota composition studies to functional studies that are now helpful in identifying the impact of microbiome environment on human health $[17,18]$. Even so, this finding is in its infancy, and the results of more extensive clinical studies must be used to corroborate the increasing quantity of associative and functional studies [19].

Tumorigenesis is one of the well-researched topics of all the pathologies associated with the gastrointestinal bacteria. The association has been established with all cancers related to gastrointestinal and other distal tumors [20]. Metabolomics and metagenomics research have illustrated that the gastrointestinal microbes play a significant part in the treatment, tumorigenesis, and anticancer therapy [21]. Indeed, the microbes of gut can be either cancer suppressive or cancer-promoting [22,23]. Research on this topic is only partially understandable but this connection has been studied for an extended period, it is only partially understood. It seems that the present understanding highlights the complex relation and bidirectionality of the 
microbiome-cancer relationship. Thus, the development of cancer may change the microbiome structure, which may influence the progression of cancer [24].

This review article illustrates the anticancer activity of gastrointestinal bacteria and their effect on immunotherapy enhancement and highlights theirs pre-clinical studies . The paper also elucidates the clinical trials of the two most used and effective probiotic strains, Lactobacillus spp and Bifidobacterium. A hypothetical debate between the two therapeutic agents: Fecal Microbial Transplantation and Probiotics, has also been described.

\section{Human Gastrointestinal Tract and Gut microbiome:}

The gastrointestinal tract and nervous system of human are associated with each other by bidirectionally through the stomach and brain axis. The gastrointestinal tract and brain axis encompasses the central, enteric nervous system, the hypothalamic pituitary adrenal axis, autonomic, and also the entero-endocrine system [24].

The gastrointestinal tract of human is consisted of liver, pancrease, esophagus, stomach, small intestine, large intestine, which begins at the mouth and ends to the anus. Its primary functions include food disruption and digestion, nutrient absorption, and waste product elimination. Given the GI tract's many functions, it's not surprising that it has a variety of environments, each of which is influenced by different variants of immune cells and the GI tract's many bacteria (figure 1)

Figure 1 : The diagram of Human Gastrointestinal Tract.

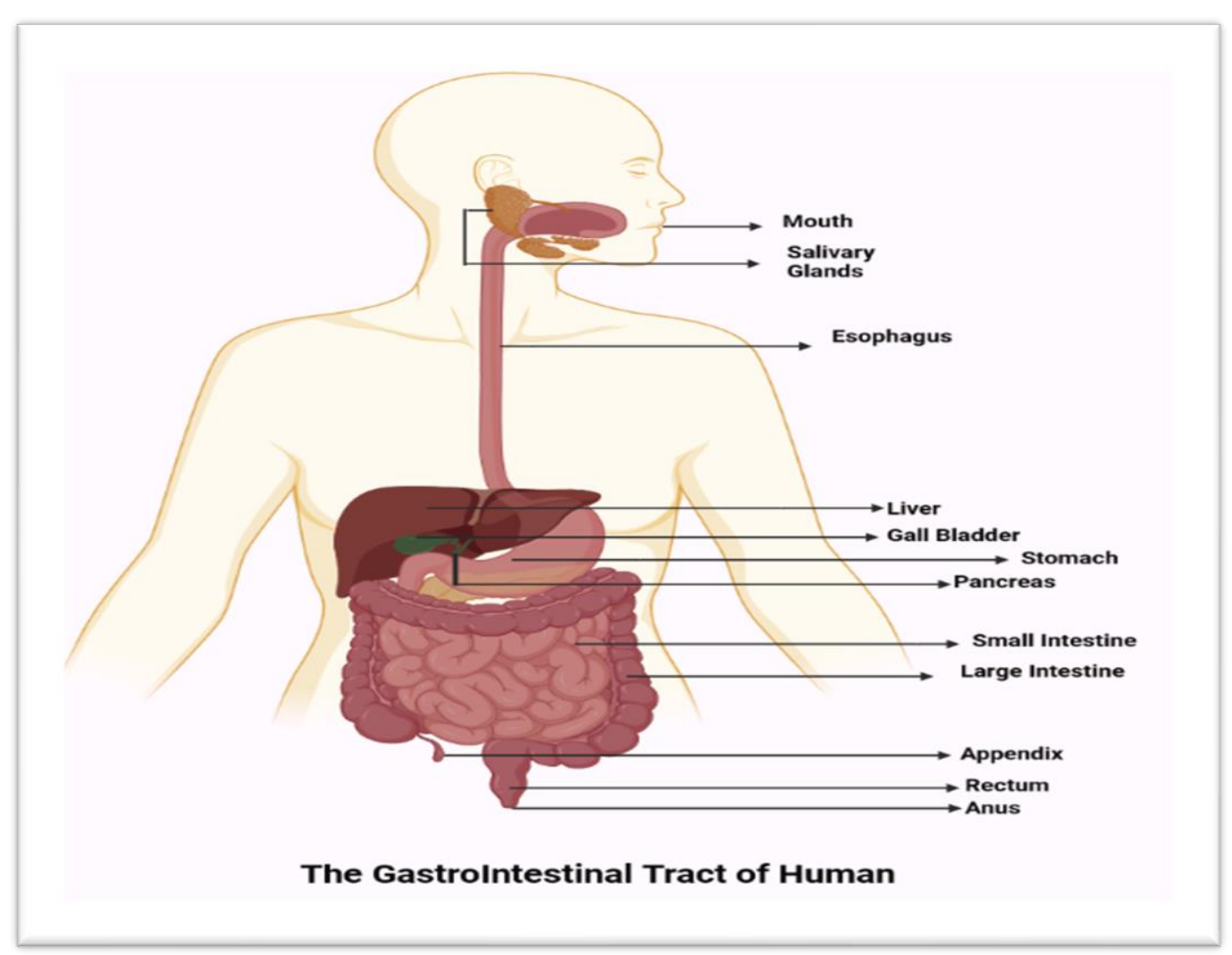


Muscle contractions help in the motion of food down to the stomach. The long tube going from mouth to anus is called esophagus which is lined with muscle and have a sphincter on the opening of stomach. The sphincter controls the passage of food. The mucous membrane which covers the muscle layers differs based on the activity of the portion of the gastrointestinal tract.

The epithelium cell lines are calve to three different layers based on their functional activity. The squamous epithelium provides a protective covering in the beginning and end of the gastrointestinal tract. The stomach has secretory epithelium. The small and large intestines both have absorptive epithelium. Multiple fingerlike extensions called villi enhance surface area to aid in nutrition absorption, with glands, that house the stem cells that give rise to epithelial cells in the small intestine. The large intestine is consisted of absorptive epithelium which is packed densely with absorptive glands which absorbs water and mucus-secreting cells that smooth the passage of excrement along the GI tract.

The tube between the innermost epithelium and muscularis propria has multiple layers and it comprises the gastrointestinal tract. The epithelium is the mucosa's innermost layer, which also includes the muscularis mucosae, a thin layer of smooth muscle and the lamina propria (a layer of supportive connective tissue). The layer beneath the mucosa that comprises nerves, lymphatic, connective tissue, and blood arteries is called submucosa. The outer muscularis propria, a muscle layer that aids in the movement of material along the GI tract, surrounds the submucosa. The adventitia or serosa is the supportive tissue that surrounds the GI tract and contains key nerves and blood arteries.

The liver and pancreas are two major glands in the GI system. They are emerged embryonically from the anterior part of the GI tract and produce stomach acids to help in the digestion. The gallbladder stores and concentrates bile, which is produced by the liver. Cholecystokinin-pancreozymin (CCK) is released by the mucosa of neuroendocrine cells whenever lipids get in the duodenum, and it causes the gallbladder to interact and secrete bile inside the duodenum. Bile acids are emulsifiers that assist in the digestion of lipids. Pancreatic secretions travel through the pancreatic duct to the duodenum and include a elevated concentration of alkaline bicarbonate ions, that help to neutralize the stomach acid. Chymotrypsin, trypsin, lipase, amylase, and carboxypeptidases are the enzymes which are produced by the pancreas and responsible for the dis-aggregation of proteins, carbohydrates, and lipids.

The gut bacteria are the microbial populations that lives in the GI tract, and it is comprised of $>10 \times 1014$ microbes which includes viruses, fungi, archaea, and bacteria. The majority portion of the gut is consisted with bacteria. The most dominant phyla are Firmicutes, Bacteroidetes, Actinobacteria, and Proteobacteria [25].

Furthermore, the composition of bacteria, in the small intestine and colon differs significantly. The variance and volume of the gut bacteria generally elevates from proximal to the site located away from specific area due to host characteristics such as $\mathrm{pH}$, mucus, gastrointestinal transport time, regional oxygen levels, bile acids, and immunological factors, as well as microbial community dynamics [4].Firmicutes, as well as Actinobacteria, Proteobacteria, and Bacteroidetes, make up the majority of the jejunal microflora, which is approximated to be 104-107 CFU/mL. Bacteroides, Enterococcus, Veillonella, Enterobacteria, Clostridium, 
and Lactobacillus are among the facultative and obligatory anaerobes found in the ileum microbiota. The microbial burden is between 103 and $108 \mathrm{CFU} / \mathrm{mL}$. Bacteroidetes, Bacteroidaceae, Lachnospiraceae, Firmicutes and Prevotellaceae, as well as stringent colonic anaerobes including Clostridium, Eubacteria, and Roseburia, which can reach 1010-1012 CFU/mL.[26-29] Generally, environmental factors, diet ,stress, sex and host genetics, initial microbial exposure, disease all dominant the structure of the gut microbiota [30,31]. Polysaccharides and their metabolites, as well as short-chain fatty acids (SCFAs), have a beneficial effect on the GI tract's bacteria $[33,33]$.

\section{Carcinogenesis induced and progressed by Gastrointestinal Bacteria:}

Gut dysbiosis is a vast concept that refers to an abnormality in the gut microbiota that relates to a negative consequence. Dysbiosis is characterized by the absence of helpful microbial input or signaling and the growth of harmful microorganisms. Dysbiosis is hypothesized to initiate pro-inflammatory effects and dysregulation of the immune system in a variety of disease conditions, including non-alcoholic steatohepatitis (NASH) [34,35].

As defined previously, it is believed to play a role in the development of a variety of immune-initiated diseases, including inflammatory bowel disease (IBD), multiple sclerosis, type 1 diabetes mellitus , cancer, rheumatoid arthritis, and systemic lupus erythematosus (SLE) [36-40] etc. Pathogenic organisms and traveler commensals cause dysbiosis (figure 2). There are several well-established risk factors which contribute to the development of cancer. Such risk factors include aging and environmental factors like hormones, smoking, xenobiotics, antibiotics, and dietary cues [41].Additionally, genetic abnormalities affecting the myeloid, epithelial, or lymphoid parts of the intestinal immune system initiate enhancement of the dysbiosis by promoting inflammatory states such as Crohn's disease, which increases the susceptibility to cancer development [42]. As a result, several variables that cause carcinogenesis also favor dysbiosis.

Studies linking intra-abdominal infections, antibiotic usage, or two of them to an elevated risk of colon cancer [43] emphasize the clinical significance of the dysbiosis-intestinal carcinogenesis relationship. Indeed, the gut microbiota has a variety of effects on colorectal oncogenesis. Eliminating or modifying the composition of the gut microbiota influences the incidence and progression of colorectal cancer in both hereditary and carcinogen-induced carcinogenesis models [44-47].

Additionally, certain gut microbiota's metabolites straightly attack intestinal epithelial cells (IECs) and either initiate carcinogenic effects (as described for hydrogen sulfide and the Bacteroides fragilis toxin) or prevent carcinogenesis (as established for SCFAs) [48]. Gastrointestinal bacteria are involved in a variety of processes, not simply colorectal carcinogenesis. Experiments on the intestinal bacteria also meditates the incidence and development of extraintestinal malignancies, such as hepatocellular and breast carcinoma, likely via metabolic and inflammatory circuits $[49,50]$.

These findings are consistent with epidemiological research demonstrating a link between dysbiosis, its repercussions or causes (most notably antibiotic overuse), and an enhanced frequency of cancers other than colonic area, including breast cancer [51,52]. Such observations can be explained by the systemic spread of microbes and their metabolites during inflammatory responses that weaken the gut barrier's integrity [49]. 
Therefore, the gut bacteria have a local and systemic effect on oncogenesis and tumor growth. While metabolic and inflammatory cues contribute to this phenomena, additive, un-characterized mode of action may also devote to dysbiosis' capacity to induce cancer.

Recent study has established a link between microbiota (particularly the gut bacteria) and carcinogenesis, implying that the gut microbiota may operate as an environmental factor and may also contribute to genetic abnormalities. The process of chronic inflammation generated by bacterial infection exemplifies the indirect bacterial mode of action of carcinogenesis. In this instance, the microbiota produces various pro-inflammatory mediators persistently, including interleukin-1 and tumor necrosis factor $-\alpha$, which additionally results in the stimulation of the NF-kB and contributes to cancer [53].

Additionally, bacteria may trigger oncogenesis directly via the action of microbial metabolites or toxins. Numerous previous research has established that several strains of gut microbiota are involved in the carcinogenesis of various forms of cancer, including gastric cancer, colorectal cancer (CRC), and hepatocellular carcinoma [53,54]. Their carcinogenic pathways are all tied to microbial metabolite synthesis. Caga proteins generated by Helicobacter pylori are transported into gastric epithelial cells and engage with the pro-oncogenic phosphatase SHP2 and the polarity-regulating kinase PAR1/MARK, activating host signaling pathways favorable for carcinogenesis [55]. Bacteroides fragilis behaves as an opportunistic pathogen and it is considered as significant risk factor for colorectal cancer (CRC) [53]. Enterotoxigenic $B$. fragilis (ETBF), one of two subtypes of B. fragilis, can stimulate inflammatory bowel disease (IBD) and colitis in antigen-presenting cell (APC) mutant mice who are predisposed to intestinal cancer, and further contribute to the carcinogenesis of colorectal cancer through the $\beta$-catenin/Wnt/NF-kB signaling pathway [53].

From the other hand, B. fragilis toxin (Bft) can cause an increase in the activity of spermine oxidase (SMO) in colon epithelial cells, resulting in the formation of reactive oxygen species (ROS) and indirect DNA damage [56,57].Several other microbial metabolites have been linked to carcinogenesis, including Pasteurella multocida toxin, cytolethal distending toxin (CDT) [53], and inositol phosphate phosphatase D (IpgD)[54].All of these factors could contribute to cell transformation, altering normal cell responses and so increasing the risk of developing cancer. 

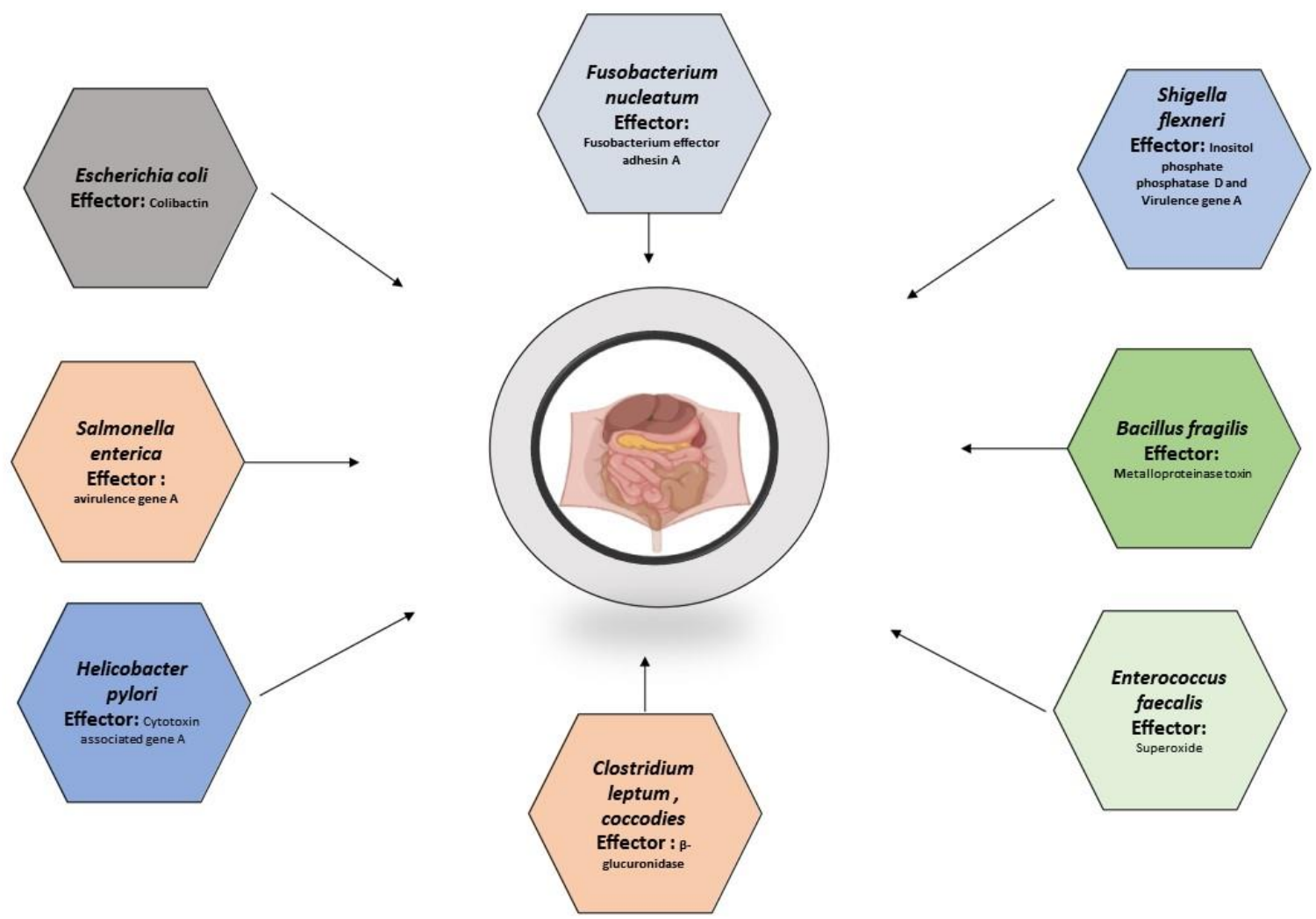

Figure 2: Names of some pathogenic bacteria and their effectors which cause dysbiosis in GI tract of human body.

The intestinal bacteria can also work as a promoter for cancer cells. The metabolites or by products which is secreted by the bacteria can induce toxicity to the previously infected or pre-disposed or damaged cells and turn them into cancerous cells. Furthermore, pertinent bacteria can promote the development of cancer by inhibiting immune effectors that typically suppress carcinogenesis.

For example, Fusobacterium nucleatum suppresses the natural Killer (NK) cells of host's to engage myeloid suppressor cells at the site of infected cells, thereby indirectly aiding cancer development. This method is regulated by the bacterial virulence component Fap2, which is capable of binding and inhibiting the NK inhibitory receptor TGIT, hence halting NK-driven tumor cell invasion.

Moreover, bacterial species may disrupt the metabolism of the host's hormones. Indeed, the relationship between bacterial release of $\beta$-glucuronidase enzymes and higher bioavailability of the host's estrogen hormones has been extensively explored and it was observed that both are originated from hepatic catabolism and phytoestrogens. Researchers have reported that the disturbance or dysbiosis of stomach is associated with an elevated number of $\beta$-glucuronidase-producing bacteria, such as Clostridium coccoides and leptum. It was found that the $\beta$-glucuronidase is capable to deconjugates liver-catabolized and plant-derived estrogens and also allow them to bind to and regulate the estrogen receptors expressed on target cells [58].The up-regulation of estrogen receptors stimulates cell proliferation in estrogen-responsive tissues such as the breast and endometrial [59]. 
As a result, this increased intake of estrogen hormones is implicated in the development of breast cancer. Data extracted from findings has shown that there is a difference in the gut bacteria of women who are suffering from breast cancer than the women are healthy. It may be possible that the numerous numbers of bacteria which was overly expressed during dysbiosis can cause the development of cancer [60].

While there are significant number of infectious bacteria who has the ability to support oncogenesis by modulating the carcinogenic cell pathways of host's or by interfering with the hormonal or immune systems, no major bacterial oncogene has been identified too yet. It is particularly challenging to determine definitively whether alterations in the microbiome influence cancer genesis or not [61].

However, modifications in the diet lifestyle, and immune system of host's have a significant impact on the composition and activity of the microbiota [62]. Additionally, the same anti-cancer medication may influence the patient's bacteria, while the patient's unique gut bacteria may have a profound effect on the patient's therapeutic efficacy.

\section{The suppression of tumor by bacterial metabolites:}

Bacterial metabolites are able to suppress the growth of tumor (figure 3). Short chain fatty acids generated by microbes may have anti-cancer properties. They have a substantial impact on health and disease by acting locally on GI tract cells, but they can also have systemic impacts by altering immune cell activity and activation states. The metabolome is the collection of tiny molecules created by a biological system, and it is a useful tool for determining the current state of that system [63].

Metabolomics is the study of metabolites utilizing techniques such as mass spectrometry, nuclear magnetic resonance, high-performance liquid chromatography, and gas chromatography with mass spectrometry. Peak patterns can be matched to spectral databases to determine which metabolites are present. To gain a better understanding of microbiomes, metabolomics can be integrated with metagenomics, which looks at the genetic material of the entire community, and meta transcriptomics, which looks at which genes are expressed. These omics approaches' merits, shortcomings, and technological obstacles have been thoroughly discussed elsewhere [64-68].

Bacterial metabolites such as butyrate and propionate, can inhibit tumor cells' histone deacetylases, resulting in a broad anti-cancer impact. Butyrate's anti-tumoral in vitro and in vivo effects in colorectal cancer (CRC) and lymphoma [69,70] are the result of this mechanism. A few of the chemicals and metabolites generated from probiotics can influence the immune system of the host which may initiate a pro-inflammatory immune response against tumor development. For instance, the intensively researched microbial lipopolysaccharide (LPS), a key element of gram-negative bacteria's outer membrane, regulates the patient's cell surface receptor toll-like receptor 4 (TLR4), which belongs to the pattern recognition receptor (PRR) family, regulating immune $\mathrm{T}$ cell-mediated responses against cancer cells [71].Likewise, Salmonella enterica secretes the monophosphorylate lipid A (MPL) which has been seen to be employed an adjuvant in anti-cervical cancer vaccination formulations [72]. 
Furthermore, a group of vitamin B named pyridoxine is produced from bacteria and can enhance the host's antitumoral immunosurveillance [73].

Figure 3: A hypothetical overview of the suppression of tumor by the application of probiotics.

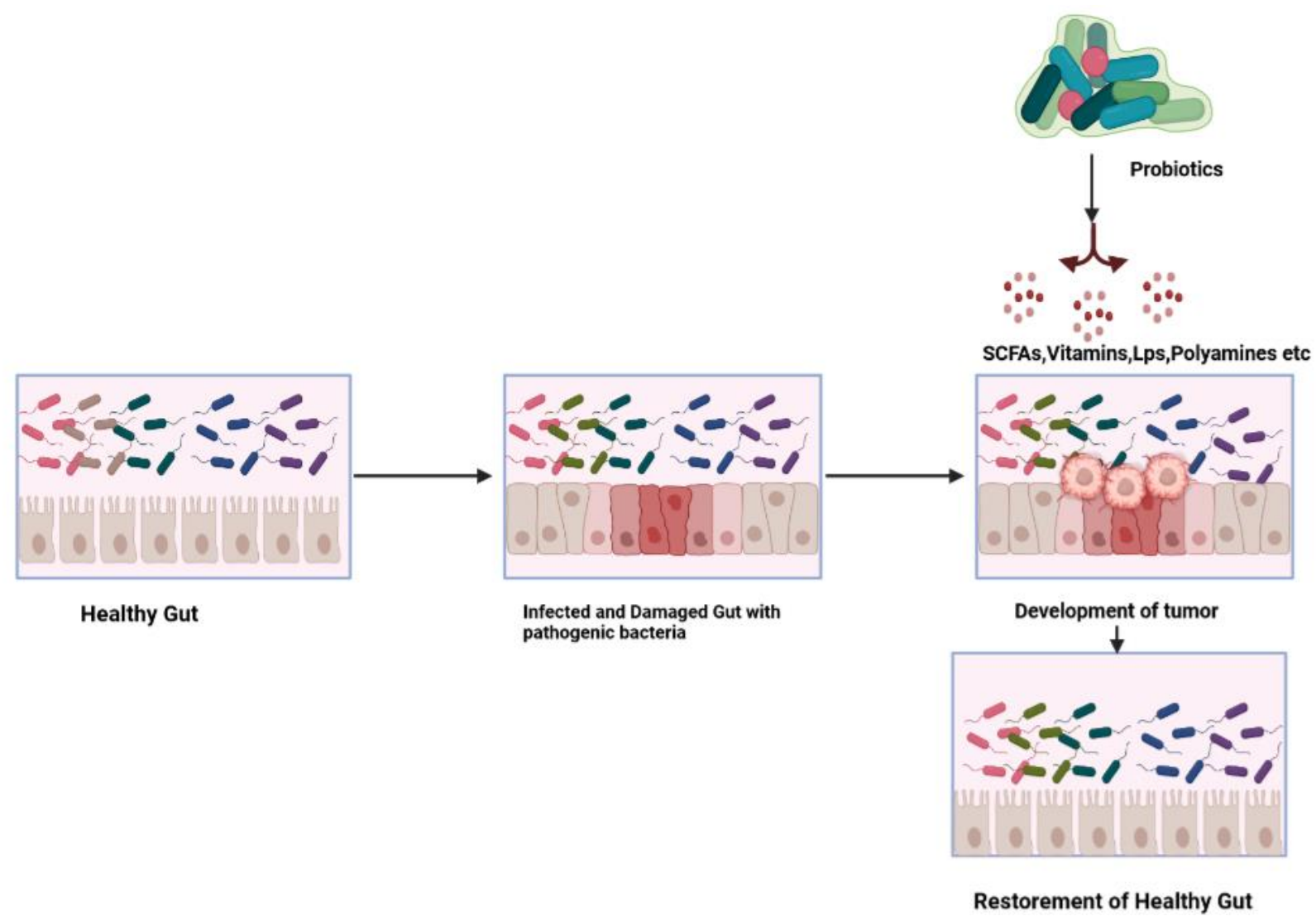

Many commensal bacteria serve as probiotics by conferring health benefits, such as preventing gut dysbiosis or improving the host's immunological defense systems. In a rat model of inflammatory bowel illness, the administration of combined drug Mutaflor which is a probiotic extracted from Escherichia coli Nissle 1917 with the antibiotic rifaximin exhibited a clear anti-inflammatory function and also the combined medication has boosted the anti-inflammatory impact of rifaximin [74].

Furthermore, many probiotics have been proven to have anticancer properties. Probiotics or probiotic-derived metabolites, for example, when given to mice, can decrease tumor growth. A prominent example is the ferrochrome metabolite released by Lactobacillus casei, which can cause apoptosis in tumor cells by directly activating the JNK pathway [75]. Lactobacilli have also been shown to stimulate host immune cells such as NK cells, dendritic cells (DC), or the TH1 response, leading to the elimination of cancerous or precancerous cells [76-79]. However, the direct bacterial metabolites which mediates a stimulatory effect has yet to be known [76-79].

Several research has been conducted by scientists, in which they have been modulated the gut bacteria and implicated them on cancer patients and observed significant changes as the engineered bacteria has shown excellent anti-cancer immunity. Potentially four independent points can be employed to change the 
consequences of the intestinal bacteria on anticancer therapeutics, I. Antibiotics, ii. Probiotics, iii. Pre-biotics, iv. Post- biotics. As this

Since of specificity concerns, using conventional antibiotics (which commonly target various kinds of Gram-positive or negative bacteria) to produce a disturbance in the gut that influence rather than antagonize the effectiveness of chemotherapeutic drugs may not be possible. Antibiotics, on the other hand, may be able to reverse a pre-existing state of harmful dysbiosis [80]. Bacterial strains who produce antibiotics such as bacteriocins and proteinaceous, can used to attack one or a few elements of the gut bacteria for medication purpose, according to new research.

Furthermore, compounds may be effective in reducing the deleterious influence of the gastrointestinal bacteria on the pharmacodynamics of various chemotherapeutical. A powerful suppressor of bacterial (but not mammalian) $\beta$-glucuronidase was demonstrated to defend mice against the intestinal adverse effects of irinotecan, extending its therapeutical panel [81].

Probiotics have been thoroughly investigated in rodent tumor models to see if they can prevent (mainly intestinal) carcinogenesis, with impressive outcomes [82,83]. Furthermore, at least in animal models, transgenic probiotics have proven successful in delivering immunostimulatory molecules, tumor-associated antigens or enzymes that reduce the toxicity of conventional chemotherapeutics [84]. Vaccines to fight against cancer are based on live and attenuated variants of Salmonella enterice and Listeria monocytogenes are currently being tested in cancer patients for their safeness and capability to raise immune responses related to therapeutics[85], reflecting significant development in the industrial and academic development of vaccines harnessing mucosal immunity $[86,87]$.

Probiotics have yet to be proven to reduce the incidence of colorectal cancer in specific patient populations, according to epidemiological research [88]. Furthermore, clinical evidence on the utilization of probiotics to reduce the intestinal noxiousness of radiotherapy and some chemo therapies is not sufficient to draw clear conclusions about their effectiveness [89]. While prebiotics (oligofructose or inulin ) and postbiotics (such as butyrate) have gotten a lot of interest as potential colorectal cancer preventatives, their capacity to broaden the therapeutic window of chemotherapy is still being studied [90].

Given current collection indicating that changes in the intestinal bacteria are beneficial, rather than harmful. To improve the effectiveness of anticancer chemotherapy, it's alluring to believe that the clinical profile of at least some chemotherapeutical can be improvise by combining antibiotics, prebiotics, probiotics, and/or postbiotics. Future experimentation is required to confirm this idea. Oncogenesis, tumor development, and response to therapy are all influenced by intestinal bacteria, according to mounting data. As a result, altering the gut microbiota specifically could be a viable way to decrease the occurrence of particular malignancies in the general population and/or (ii) ameliorate the effectiveness of various anticancer drugs. 


\section{Probiotics: The modified gut bacteria with anti-cancer immunity/activity (In vivo and In vitro studies) :}

Probiotics are known to be the good gut bacteria which uphold a greater perspective in the treatment of cancer. The use of probiotics has grown in importance as a research topic. Probiotics have been consumed by humans since 1907. Lactic acid bacteria and Bifidobacteria have dominated the market for more than a century. Bifidobacterium (adolescentis, animalis, bifidum, breve, and longum) and Lactobacillus (acidophilus, casei, fermentum, gasseri, johnsonii, paracasei, plantarum, rhamnosus, and salivarius) are the two most frequently used species on the market.

Some additional strains, such as Roseburia spp., Akkermansia spp., and Faecalibacterium spp., appear to be promising for human health and deserve more investigation. Probiotics are live bacterial species that are injected into the human body and have therapeutic benefits by restoring the normal microbiota ecosystem [91]. The impact of probiotics on tumor-therapy-related toxicity [92] and their potential for increasing cancer treatment efficiency have received a lot of attention [93]. Preoperative treatment of probiotics, prebiotics, and synbiotic (a combination of probiotics and prebiotics) successfully reduces post-operative infection, reducing inflammation, morbidity, and hospital stay, according to research findings [94]. This is accomplished through altering the microbiota's diversity and strengthening the intestinal barrier [95].

Furthermore, probiotic nutrition strategies, such as the administration of probiotic Bifico against chemoradiotherapy-induced oral mucositis and the use of "designer probiotics" in CRC and breast cancer, have been shown to be effective against radiotherapy-induced side effects by enhancing immune response [96]. Notably, new evidence suggests that administering certain bacteria strains, such as Lactobacillus spp. and Bifidobacteriales, is linked to improved anticancer activity.

The first two scientists who demonstrate a link between a Lactobacillus-enriched diet and a decreased risk of colorectal cancer (by 37 percent compared to controls) was Goldin and Gorbach. Numerous in vitro studies demonstrate that probiotics have positive effects on the multiplication and death of cancer cells, including colonic, gastric, and myeloid leukemia cells. Studies illustrate that the strain Lactobacillus rhamnosus GG has a substantial antiproliferative effect and/or induces apoptosis in human colonic cancer cells (Caco-2, DLD-1, HT-29) and mus musculus colon carcinoma (HGC-27) [97-103] as well as a reduction of IL-8 [104].

Additionally, researchers' findings indicate the efficacy of probiotic microorganisms (e.g., Lactobacillus acidophilus, fermentum, plantarum, salivarius, helveticus, paracasei, delbrueckii, pentosus, Bacillus polyfermenticus, subtilis; Lactococcus lactis,; adolescentis; Clostridium butyricum; Enterococcus faecium; casei, Bifidobacterium lactis, Pediococcus pentosaceus, Propionibacterium acidopropionici, Streptococcus thermophilus) in the reduction of multiplication and/or initiation of apoptosis of human colonic cancer cells such as HT-29, Caco-2, SW1116, HCT116, DLD-1, LoVo, SW480, .Additionally, Lactobacillus acidophilus CL1285 and Lactobacillus casei LBC80R stimulated apoptosis in human colorectal cells (LS513) in the presence of 5-FU [105], whereas Lactobacillus casei YIT9029, Lactobacillus acidophilus SNUL, and Bifidobacterium longum HY8001 inhibited the development of human colorectal 
(SNUC2A) and stomach cancer. A medicine named 5-fluorouracil (5-FU), a chemotherapy medication, frequently has an effect on the development of diarrhea. Bacillus polyfermenticus was reported to have a good influence on colony development in human colonic epithelial cells (NMC460) [106]. Numerous investigations on probiotics' antitumor effects are conducted in animal models.

Most of this type of research yielded good results and suggested a possible clinical application. The effects of probiotic microorganisms on tumor-bearing or tumor-induced animals.

These findings demonstrate that probiotics possess anti-cancer capabilities Bifidobacterium infantum,. Bacillus polyfermenticus, and Bifidobacterium bifidum, and Lactobacillus acidophilus, casei, lactis, rhamnosus, plantarum, and salivarius greatly reduced the formation of colon cancer in rodent models injected with the carcinogenic 1,2-dimethylhydrazine (DMH) .

Pediococcus pentosaceus or Lactobacillus plantarum are types of probiotics which have been shown in many studies to induce death and reduce the incidence of azoxymethane (AOM)-induced cancer in mice [107,108]. The administration of probiotics mixture VSL\#3 or Lactobacillus plantarum to mice reduced the incidence of dextran sulfate sodium (DSS)-induced cancer [109] or Lactobacillus plantarum [107]. Probiotics (L. plantarum, combination VSL\#3, B. polyfermenticus, L. rhamnosus, and B. lactis KCTC 5727) were found to be useful in the treatment of cancer generated by the injection of CT26 cells, DLD-1, TNBS or MNNG, cells, or in the absence of injection. Although the encouraging results, they should be taken cautiously because the majority of tumors were created by diverse chemical agents, a process that differs significantly from spontaneous carcinogenesis. In the following table 1 and table 2 , the in vitro and in vivo studies of probiotics against distinct variety of cancer are jotted down: 
Table 1 : In vitro studies of Probiotic strains against cancer

\begin{tabular}{|c|c|c|c|c|}
\hline $\begin{array}{c}\text { Names of } \\
\text { Probiotic strains }\end{array}$ & $\begin{array}{c}\text { Types of } \\
\text { Cancer Cell } \\
\text { Line }\end{array}$ & Results & Study Type & References \\
\hline $\begin{array}{l}\text { Lactobacillus casei } \\
\quad \text { ATCC } 393\end{array}$ & $\begin{array}{l}\text { HT29 and } \\
\text { CT26 }\end{array}$ & Apoptosis was induced in the cancer cells. & In vitro & 109 \\
\hline $\begin{array}{l}\text { Bacillus } \\
\text { polyfermenticus } \\
\text { KU3 }\end{array}$ & $\begin{array}{l}\text { LoVo, HT-29, } \\
\text { AGS }\end{array}$ & $\begin{array}{l}\text { The proliferation of cancer cells was decreased } \\
\text { to }>90 \%\end{array}$ & In vitro & 106 \\
\hline $\begin{array}{l}\text { Lactobacillus } \\
\text { pentosus } \mathrm{B} 281 \\
\text { Lactobacillus } \\
\text { plantarum } \mathrm{B} 282\end{array}$ & $\begin{array}{l}\text { Caco-2 and } \\
\text { HT-29 }\end{array}$ & $\begin{array}{c}\text { The proliferation of cancer cells was decreased and } \\
\text { cell cycle arrest was observed in the gastrointestinal } \\
\text { tract ) }\end{array}$ & In vitro & 110 \\
\hline $\begin{array}{l}\text { Lactococcus lactis } \\
\text { NK34 }\end{array}$ & $\begin{array}{l}\text { HT-29, LoVo, } \\
\text { AGS }\end{array}$ & $\begin{array}{l}\text { The proliferation of cancer cells was decreased } \\
\text { to }>80 \%\end{array}$ & In vitro & 111 \\
\hline $\begin{array}{l}\text { Lactobacillus } \\
\text { reuteri ATCC PTA } \\
6475\end{array}$ & KBM-5 & The cancer cell apoptosis was increased & In vitro & 112 \\
\hline $\begin{array}{l}\text { Lactobacillus } \\
\text { rhamnosus } \mathrm{GG}\end{array}$ & Caco-2 & The level of interleukin 8 was decreased & In vitro & 104 \\
\hline $\begin{array}{l}\text { Bifidobacterium } \\
\text { adolescentis } \\
\text { SPM0212 }\end{array}$ & $\begin{array}{l}\text { Caco-2, HT-29, } \\
\text { SW480 }\end{array}$ & Cell proliferation was decreased & In vitro & 113 \\
\hline $\begin{array}{l}\text { Lactobacillus } \\
\text { rhamnosus GG }\end{array}$ & HGC-27 & $\begin{array}{l}\text { The cell proliferation was decreased and the } \\
\text { apoptosis of cells were observed. }\end{array}$ & In vitro & 101 \\
\hline $\begin{array}{c}\text { Lactobacillus } \\
\text { acidophilus SNUL } \\
\text { Lactobacillus casei } \\
\text { YIT9029 } \\
\text { Bifidobacterium } \\
\text { longum HY8001 }\end{array}$ & $\begin{array}{l}\text { SNUC2A, } \\
\text { SNU1, } \\
\text { NIH/3T3 and } \\
\text { Jurkat cell }\end{array}$ & $\begin{array}{l}\text { Successfully suppressed the proliferation of cancer } \\
\text { cell }\end{array}$ & In vitro & 77 \\
\hline $\begin{array}{l}\text { Propionibacterium } \\
\text { acidopropionici } \\
\text { CNRZ80 }\end{array}$ & HT-29 & $\begin{array}{l}\text { Cell proliferation was decreased and the cells were } \\
\text { induced to go to apoptosis }\end{array}$ & In vitro & 114 \\
\hline $\begin{array}{l}\text { Propionibacterium } \\
\text { freudenreichii ITG } \\
\text { P9 }\end{array}$ & HGT-1 & Cancer cells were induced to apoptosis & In vitro & 69 \\
\hline $\begin{array}{c}\text { Lactobacillus } \\
\text { paracasei } \\
\text { IMPC } 2.1 \\
\text { Lactobacillus } \\
\text { rhamnosus GG }\end{array}$ & $\begin{array}{l}\text { DLD-1, } \\
\text { HGC-27 }\end{array}$ & $\begin{array}{l}\text { The cell proliferation was decreased and the } \\
\text { apoptosis of cells were observed. }\end{array}$ & In vitro & 100 \\
\hline $\begin{array}{l}\text { Lactobacillus } \\
\text { rhamnosus } \mathrm{GG} \\
\text { Bifidobacterium } \\
\quad \text { lactis } \mathrm{Bb} 12\end{array}$ & HT-29 & The apoptosis of cells was observed. & In vitro & 78 \\
\hline
\end{tabular}




\begin{tabular}{|c|c|c|c|c|}
\hline $\begin{array}{l}\text { Lactobacillus } \\
\text { acidophilus } \\
\text { CL1285 } \\
\text { Lactobacillus casei } \\
\text { LBC80R } \\
\text { (in the presence of } \\
\text { 5-FU) }\end{array}$ & LS513 & Cell apoptosis was increased to $40 \%$ & In vitro & 115 \\
\hline $\begin{array}{l}\text { Lactobacillus } \\
\text { acidophilus } 606\end{array}$ & HT-29 & Cell proliferation was decreased & In vitro & 116 \\
\hline $\begin{array}{c}\text { Bacillus } \\
\text { polyfermenticus }\end{array}$ & NMC460 & $\begin{array}{l}\text { Decrease in the cell colony formation in cancer } \\
\text { cells }\end{array}$ & In vitro & 117 \\
\hline $\begin{array}{l}\text { Enterococcus } \\
\text { faecalis } \\
\text { CECT71 } 121\end{array}$ & LBC & $\begin{array}{l}\text { The multiplication of tumor cells was decreased } \\
\text { and cell apoptosis was observed }\end{array}$ & In vitro & 118 \\
\hline $\begin{array}{l}\text { Lactobacillus } \\
\text { rhamnosus } \mathrm{GG} \\
\text { Bifidobacterium } \\
\text { lactis } \mathrm{Bb} 12\end{array}$ & Caco-2 & Apoptosis of the cancer cell was observed & In vitro & 98 \\
\hline $\begin{array}{c}\text { Enterococcus } \\
\text { faecium } \mathrm{RM} 11 \\
\text { Lactobacillus } \\
\text { fermentum } \mathrm{RM} 28\end{array}$ & Caco-2 & $\begin{array}{l}\text { Cancer cell proliferation was decreased to } 21 \% \text { and } \\
\qquad 31 \% .\end{array}$ & In vitro & 118 \\
\hline $\begin{array}{c}\text { Clostridium } \\
\text { butyricum ATCC } \\
\text { Bacillus subtilis } \\
\text { ATCC } 9398\end{array}$ & $\begin{array}{l}\text { HCT116, } \\
\text { SW1116, } \\
\text { Caco-2 }\end{array}$ & The proliferation of cancer cells was decreased & In vitro & 119 \\
\hline $\begin{array}{c}\text { Lactobacillus } \\
\text { plantarum A7 } \\
\text { Lactobacillus } \\
\text { rhamnosus GG }\end{array}$ & Сасо-2, НT-29 & The proliferation of cancer cells was decreased & In vitro & 103 \\
\hline $\begin{array}{c}\text { Lactobacillus kefiri } \\
\text { P-IF }\end{array}$ & MDR & Apoptosis of the cancer cell was observed & In vitro & 120 \\
\hline $\begin{array}{c}\text { Pediococcus } \\
\text { pentosaceus FP3 } \\
\text { Lactobacillus } \\
\text { salivarius } \\
\text { FP25/FP35 } \\
\text { Enterococcus } \\
\text { faecium } \text { FP51 }\end{array}$ & Caco-2 & $\begin{array}{l}\text { The proliferation of cancer cells was decreased. } \\
\text { Activation of apoptosis was observed }\end{array}$ & In vitro & 121 \\
\hline
\end{tabular}


Table 2 : In vivo experiments of probiotic strains on animal model

\begin{tabular}{|c|c|c|c|c|}
\hline $\begin{array}{c}\text { Names of Probiotic } \\
\text { strains }\end{array}$ & $\begin{array}{c}\text { Animal Model } \\
\text { types }\end{array}$ & $\begin{array}{l}\text { Types of Injected } \\
\text { Cancer Cell lines }\end{array}$ & Results & Reference \\
\hline $\begin{array}{l}\text { Lactobacillus } \\
\text { rhamnosus } \\
231(\operatorname{Lr} 231)\end{array}$ & rats & $\begin{array}{l}\text { N-Methyl-N'- } \\
\text { Nitro- } \\
\text { Nitrosoguanidine; }\end{array}$ & $\begin{array}{c}\text { The fecal activity of azoreductase } \\
\text { and nitroreductase was decreased, } \\
\text { The level of glutathione was } \\
\text { decreased and the level of } \\
\text { glutathione } S \text {-transferase was } \\
\text { elevated. }\end{array}$ & 122 \\
\hline $\begin{array}{l}\text { VSL\#3 (Probiotics } \\
\text { mixture) }\end{array}$ & $\begin{array}{l}\text { Sprague-- } \\
\text { Dawley rat }\end{array}$ & $\begin{array}{l}\text { trinitrobenzene } \\
\text { sulfonic acid }\end{array}$ & $\begin{array}{l}\text { The cells of colorectal cancer were } \\
\text { not observed which means that } \\
\text { none of the rat models have } \\
\text { developed colorectal cancer }\end{array}$ & 123 \\
\hline $\begin{array}{l}\text { Lactobacillus } \\
\text { plantarum }\end{array}$ & $\begin{array}{l}\text { Wistar albino } \\
\text { rats }\end{array}$ & $\begin{array}{l}\text { 1,2-dimethylhydra } \\
\text { zine } \\
\text { dihydrochloride }\end{array}$ & $\begin{array}{l}\text { The level of the activities of } \\
\text { bacterial enzymes were found to be } \\
\text { decreased, but the fecal bile acids } \\
\text { concentration serum serum tumor } \\
\text { necrosis factor-alpha level was } \\
\text { elevated }\end{array}$ & 124 \\
\hline $\begin{array}{c}\text { Bacillus } \\
\text { polyfermenticus }\end{array}$ & CD-1 mice & DLD-1 cells & $\begin{array}{l}\text { The development of new tumor } \\
\text { was decreased and also the volume } \\
\text { of tumor got decreased too. }\end{array}$ & 116 \\
\hline $\begin{array}{l}\text { Bifidobacterium lactis } \\
\text { KCTC } 5727\end{array}$ & SPF C57BL rat & - & $\begin{array}{l}\text { The development of new tumor } \\
\text { was decreased and also the volume } \\
\text { of tumor got decreased too. }\end{array}$ & 117 \\
\hline $\begin{array}{l}\text { Lactobacillus } \\
\text { acidophilus, } \\
\text { Lactobacillus casei } \\
\text { Lactobacillus lactis } \\
\text { biovar diacetylactis } \\
\text { DRC-1 }\end{array}$ & Rat & $\begin{array}{l}\text { 1,2-dimethylhydra } \\
\text { zine } \\
\text { dihydrochloride }\end{array}$ & $\begin{array}{l}\text { The development, volume and } \\
\text { proliferation of tumor were } \\
\text { decreased. }\end{array}$ & 125 \\
\hline $\begin{array}{c}\text { Bacillus } \\
\text { polyfermenticus }\end{array}$ & F344 rats & $\begin{array}{c}\text { 1,2-dimethylhydra } \\
\text { zine } \\
\text { dihydrochloride }\end{array}$ & $\begin{array}{c}\text { aberrant crypt foci was decreased } \\
\text { by } 50 \% \text { though the anti-oxidant } \\
\text { levels were elevated }\end{array}$ & 126 \\
\hline $\begin{array}{l}\text { Lactobacillus } \\
\text { plantarum (AdF10) } \\
\text { Lactobacillus } \\
\text { rhamnosus GG }\end{array}$ & $\begin{array}{c}\text { Sprague-- } \\
\text { Dawley rat }\end{array}$ & $\begin{array}{c}\text { 1,2-dimethylhydra } \\
\text { zine } \\
\text { dihydrochloride } \\
\text { 4weeks }\end{array}$ & $\begin{array}{l}\text { The development, volume and } \\
\text { proliferation of tumor were } \\
\text { decreased. }\end{array}$ & 127 \\
\hline $\begin{array}{l}\text { VSL\#3 (Probiotics } \\
\text { mixture) }\end{array}$ & C57BL/6 mice & $\begin{array}{l}\text { dextran sulfate } \\
\text { sodium }\end{array}$ & $\begin{array}{c}\text { The development of tumor and } \\
\text { dysplasia was decreased }\end{array}$ & 103 \\
\hline $\begin{array}{l}\text { Lactobacillus } \\
\text { plantarum }\end{array}$ & $\mathrm{BALB} / \mathrm{c}$ mice & $\begin{array}{l}\text { CT26 cells } \\
\text { injection }\end{array}$ & $\begin{array}{l}\text { The volume of tumor was } \\
\text { decreased and necrosis of the cells } \\
\text { were induced }\end{array}$ & 128 \\
\hline $\begin{array}{l}\text { Lactobacillus } \\
\text { plantarum }\end{array}$ & $\mathrm{BALB} / \mathrm{c}$ mice & $\begin{array}{l}\text { Azoxymethane, de } \\
\text { xtran sulfate } \\
\text { sodium }\end{array}$ & $\begin{array}{l}\text { New tumor formation was stopped } \\
\text { so does the cell division. Necrosis } \\
\text { of the cells was induced. }\end{array}$ & 106 \\
\hline $\begin{array}{c}\text { Lactobacillus } \\
\text { rhamnosus GG MTCC }\end{array}$ & Sprague- & $\begin{array}{c}\text { 1,2-dimethylhydra } \\
\text { zine }\end{array}$ & $\begin{array}{l}\text { The multiplication and } \\
\text { development of new tumor has }\end{array}$ & 129 \\
\hline
\end{tabular}




\begin{tabular}{|c|c|c|c|c|}
\hline $\begin{array}{c}\# 1408 \\
\text { Lactobacillus } \\
\text { acidophilus } \text { NCDC \#1 }\end{array}$ & Dawley rat & dihydrochloride & been stopped & \\
\hline $\begin{array}{l}\text { Lactobacillus } \\
\text { acidophilus KFRI342 }\end{array}$ & F344 rats & $\begin{array}{l}\text { 1,2-dimethylhydra } \\
\text { zine } \\
\text { dihydrochloride }\end{array}$ & $\begin{array}{l}\text { aberrant crypt foci were decreased } \\
\quad \text { and also the level of } \\
\beta \text {-glucuronidase and } \beta \text {-glucosidase } \\
\text { activity was decreased too. }\end{array}$ & 130 \\
\hline $\begin{array}{l}\text { Lactobacillus casei } \\
\text { BL23 }\end{array}$ & C57BL/6 mice & $\begin{array}{l}\text { 1,2-dimethylhydra } \\
\text { zine } \\
\text { dihydrochloride }\end{array}$ & New tumor formation was stopped. & 76 \\
\hline $\begin{array}{c}\text { Pediococcus } \\
\text { pentosaceus GS4 }\end{array}$ & $\begin{array}{l}\text { Swiss albino } \\
\text { mice }\end{array}$ & azoxymethane & $\begin{array}{l}\text { The progression of tumor was } \\
\text { stopped and the cells went to } \\
\text { apoptosis. }\end{array}$ & 107 \\
\hline $\begin{array}{c}\text { Lactobacillus } \\
\text { rhamnosus } \mathrm{GG} \\
\text { CGMCC } 1.2134\end{array}$ & $\begin{array}{l}\text { Sprague- } \\
\text { Dawley rat }\end{array}$ & $\begin{array}{l}\text { 1,2-dimethylhydra } \\
\text { zine } \\
\text { dihydrochloride }\end{array}$ & $\begin{array}{l}\text { The development, volume and } \\
\text { proliferation of tumor were } \\
\text { decreased. Apoptosis was induced. }\end{array}$ & 131 \\
\hline $\begin{array}{c}\text { Lactobacillus } \\
\text { acidophilus } \\
\text { Bifidobacterium } \\
\text { bifidum } \\
\text { Bifidobacterium } \\
\text { infantum }\end{array}$ & $\begin{array}{l}\text { Sprague- } \\
\text { Dawley rat }\end{array}$ & $\begin{array}{l}\text { 1,2-dimethylhydra } \\
\text { zine } \\
\text { dihydrochloride } \\
\text { antibiotics }\end{array}$ & $\begin{array}{l}\text { The development, volume of } \\
\text { tumor was decreased. }\end{array}$ & 132 \\
\hline $\begin{array}{l}\text { Lactobacillus } \\
\text { salivarius } \text { Ren }\end{array}$ & F344 rats & $\begin{array}{c}\text { 1,2-dimethylhydra } \\
\text { zine } \\
\text { dihydrochloride }\end{array}$ & $\begin{array}{l}\text { The development of tumor was } \\
\text { decreased. }\end{array}$ & 133 \\
\hline
\end{tabular}

Up to now, we have seen that the application of Lactobacillus spp, and Bifidobacterium spp. in cancer treatment has demonstrated successful potential outcomes. The other known probiotic strains ruling in markets are Roseburia spp., Akkermansia spp., and Faecalibacterium spp., which also contain anti-cancer immunity. In the following context, we will go through the clinical trials of Lactobacillus spp, and Bifidobacterium spp.

\section{Lactobacillus spp:}

Among Lactobacillus species, the most successful probiotic model is Lactobacillus rhamnosus GG. It is the most studied and well-characterized probiotic archetypes because of its anti-inflammatory capabilities. Probiotics, especially Lactobacilli, are being investigated as a therapeutic option for patients who have gastrointestinal damage due to chemotherapy, and also because of their potential to restore gut microbial balance[134]. LGG was one of the first probiotic species to be examined specifically in cancer [135]. It is a gut-resident bacteria that has anti-inflammatory properties in the intestinal milieu. LGG provided along meals decreases 5-FU and radiation-induced gut epithelial injury in animal models, hence assisting in the maintenance of gut microbiota balance and intestinal epithelial barrier integrity [136-138]. 
Numerous potentials of LGG medication to patients have been demonstrated over a long period of time through experimental and clinical research [139]. In accordance with these findings, a large number of clinical trials are ongoing which are examining the function of LGG administration in preventing or ameliorating the adverse effects of anti-cancer therapy . In the following table 3 the completed and active clinical trials of Lactobacillus spp are described below:

Table 3 : Clinical trials of the application and effects of probiotic Lactobacillus rhamnosus $G G$ against cancers

\begin{tabular}{|c|c|c|c|c|}
\hline $\begin{array}{l}\text { ClinicalTrials.gov } \\
\text { Identifier }\end{array}$ & Types of Cancer & Topic & Dosage of Drug & Status \\
\hline NCT02751736 & Rectal Cancer & $\begin{array}{c}\text { The effect of probiotics on } \\
\text { bowel function restoration } \\
\text { after ileostomy closure in } \\
\text { patients with RC }\end{array}$ & $\begin{array}{l}\text { probiotic } \\
C J L P 243\end{array}$ & Active \\
\hline NCT03290651 & Breast Cancer & $\begin{array}{l}\text { Probiotics and breast } \\
\text { health }\end{array}$ & $\begin{array}{c}\text { probiotic } \\
\text { RepHresh Pro-B }\end{array}$ & Active \\
\hline NCT03518268 & Breast Cancer & $\begin{array}{l}\text { Vivomixx for prevention of } \\
\text { bone loss in women with } \\
\text { BC treated with an } \\
\text { aromatase inhibitor }\end{array}$ & probiotic Vivomixx & Active \\
\hline NCT03177681 & Multiple types & $\begin{array}{l}\text { The effect of yogurt in } \\
\text { cancer patient with } \\
\text { moderate GI symptoms }\end{array}$ & $\begin{array}{l}\text { DS: probiotics in } \\
\text { yogurt }\end{array}$ & Active \\
\hline NCT03642548 & $\begin{array}{l}\text { Non-Small Cell } \\
\text { Lung Cancer }\end{array}$ & $\begin{array}{l}\text { Probiotics combined with } \\
\text { chemotherapy for patients } \\
\text { with advanced NSCLC }\end{array}$ & $\begin{array}{l}\text { Drug with DS of } \\
\text { probiotic Bifico }\end{array}$ & Active \\
\hline NCT03358511 & Breast Cancer & $\begin{array}{l}\text { Engineering gut } \\
\text { microbiome to target } \mathrm{BC}\end{array}$ & $\begin{array}{c}\text { DS: Probiotic } \\
\text { Primal Defense } \\
\text { Ultra }\end{array}$ & Active \\
\hline NCT02944617 & Renal Cell Cancer & $\begin{array}{l}\text { Probiotic yogurt } \\
\text { supplement in reducing } \\
\text { diarrhea in patients with } \\
\text { metastatic kidney cancer } \\
\text { being treated with } \\
\text { VEGF-TK inhibitor }\end{array}$ & $\begin{array}{l}\text { probiotics in } \\
\text { yogurt }\end{array}$ & Active \\
\hline NCT02351089 & $\begin{array}{l}\text { Gynecologic } \\
\text { Cancer }\end{array}$ & $\begin{array}{c}\text { Probiotics in } \\
\text { radiation-treated } \\
\text { gynecologic cancer } \\
\text { (ProRad) }\end{array}$ & LGG & Active \\
\hline NCT03574051 & Thyroid Cancer & $\begin{array}{l}\text { Microbiota are associated } \\
\text { with Iodine-131 therapy } \\
\text { and hypothyroidism }\end{array}$ & $\begin{array}{c}\text { Iodine-131 } \\
\text { Therapy with DS } \\
\text { of probiotics }\end{array}$ & Active \\
\hline NCT03552458 & $\begin{array}{l}\text { Head-and-neck } \\
\text { Cancer }\end{array}$ & $\begin{array}{l}\text { Effects of Probiotics in } \\
\text { preventing oral mucositis } \\
\text { in patients undergoing }\end{array}$ & L Reuteri & Active \\
\hline
\end{tabular}




\begin{tabular}{|c|c|c|c|c|}
\hline & & $\begin{array}{l}\text { head and neck } \\
\text { radiotherapy }\end{array}$ & & \\
\hline NCT02819960 & Colorectal cancer & $\begin{array}{c}\text { prevention of } \\
\text { irinotecan-induced } \\
\text { diarrhea by probiotics }\end{array}$ & $\begin{array}{l}\text { Probio-Fixinum } \\
\text { (including LGG) }\end{array}$ & Active \\
\hline NCT01790035 & GI Cancer & $\begin{array}{l}\text { Probiotic LGG for } \\
\text { prevention of side-effects } \\
\text { in patients undergoing } \\
\text { chemoradiation for GI } \\
\text { cancer }\end{array}$ & LGG & Active \\
\hline NCT00197873 & Colorectal Cancer & $\begin{array}{c}\text { Lactobacillus Rhamnosus } \\
\text { in prevention of } \\
\text { chemotherapy-related } \\
\text { diarrhea }\end{array}$ & LGG & Active \\
\hline NCT00936572 & Colorectal Cancer & Probiotics in CRC patients & probiotic $L a l$ & Completed \\
\hline NCT01839721 & $\begin{array}{l}\text { Multiple types of } \\
\text { Cancers }\end{array}$ & $\begin{array}{l}\text { Impact of probiotics on } \\
\text { diarrhea in patients treated } \\
\text { with pelvic radiation }\end{array}$ & probiotic Bifilact & Completed \\
\hline NCT01410955 & Colorectal Cancer & $\begin{array}{c}\text { Prevention of } \\
\text { irinotecan-induced } \\
\text { diarrhea by probiotics }\end{array}$ & $\begin{array}{l}\text { DS: probiotic } \\
\text { Colon Dophilus }\end{array}$ & Completed \\
\hline NCT01479907 & Colorectal Cancer & $\begin{array}{c}\text { Synbiotics and GI } \\
\text { function-related quality of } \\
\text { life after colectomy for } \\
\text { cancer }\end{array}$ & $\begin{array}{l}\text { prebiotics and } \\
\text { probiotics } \\
\text { Synbiotic Forte }\end{array}$ & Completed \\
\hline NCT01609660 & Colorectal Cancer & $\begin{array}{l}\text { Impact of probiotics on the } \\
\text { intestinal microbiota }\end{array}$ & $S$ boulardii & Completed \\
\hline NCT03072641 & Colon Cancer & $\begin{array}{c}\text { Using probiotics to } \\
\text { reactivate } \\
\text { tumor-suppressor genes in } \\
\text { CRC }\end{array}$ & $\begin{array}{c}\text { probiotic ProBion } \\
\text { Clinica }\end{array}$ & Completed \\
\hline NCT01468779 & $\begin{array}{l}\text { Periampullary } \\
\text { Carcinoma }\end{array}$ & $\begin{array}{l}\text { Effect of probiotics in } \\
\text { patients undergoing } \\
\text { surgery for periampullary } \\
\text { neoplasms }\end{array}$ & DS: probiotics & Completed \\
\hline NCT01895530 & Colorectal Cancer & $\begin{array}{l}\text { Impact of probiotics in } \\
\text { modulation of intestinal } \\
\text { microbiota }\end{array}$ & DS: $S$ boulardii & Completed \\
\hline NCT03420443 & Rectal Cancer & $\begin{array}{l}\text { Action of synbiotics on } \\
\text { irradiated GI mucosa in } \\
\text { RC treatment (FIPIREX) }\end{array}$ & DS: probiotics & Completed \\
\hline NCT02771470 & Lung Cancer & $\begin{array}{l}\text { Intestinal microbiota in } \\
\text { lung cancer after } \\
\text { chemotherapy }\end{array}$ & DS: probiotics & Completed \\
\hline NCT02021253 & $\begin{array}{l}\text { Hepatocellular } \\
\text { Carcinoma }\end{array}$ & $\begin{array}{l}\text { Influence of probiotics } \\
\text { administration before liver } \\
\text { resection in liver disease }\end{array}$ & DS: probiotics & Completed \\
\hline
\end{tabular}




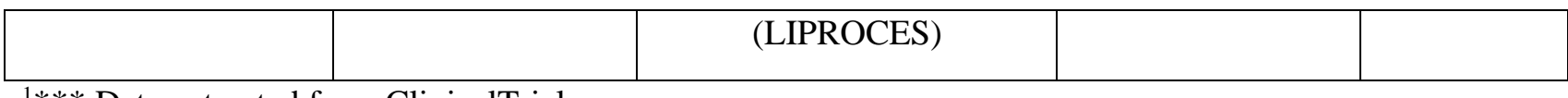

1*** Data extracted from ClinicalTrials.gov

Certain lactobacillus has recently been revealed to contain anticancer effects. However, the impact of lactobacilli on cancer cell viability or tumor size is mostly concentrated on the investigations $[77,142]$. According to researchers' oral administration of Lactobacillus rhamnosus can decrease the $\beta$ -glucuronidase of fecal concentration in humans, signifying a reduction in the conversion of procarcinogens to carcinogens [143]. A study reported how Lactobacillus rhamnosus and Lactobacillus casei soluble factors have caused apoptosis in a human monocytic leukemia cell line [144].

Numerous research has been done on antimutagenic activity in which milk was fermented and then cultured with several lactic acid producing bacteria and yeast. The research has demonstrated that fermented and cultured milk have exhibited a broader extent of activity against mutagens than normal milk generally produces with a single strain of lactic acid bacteria [145]. In 2013, two scientists have discovered same results when they experimented the anticancer activity of goat milk hydrolysate fermented with Lactobacillus plantarum and Lactobacillus paracasein[146]. Choi et al. (2006) investigated the inhibitory effects of Lactobacillus on various human cancer cell lines (L. rhamnosus GG, L. casei ATCC 393, L. acidophilus 606, and L. brevis ATCC 8287) [147]. Additionally, the anticancer properties of membrane components or peptidoglycans of the cell walls of numerous LAB strains, including Lactobacillus, have been evaluated [142]. Choi et al. 2006 discovered that the soluble polysaccharide component of Lactobacillus acidophilus HK cells inhibited multiplication of cancer cells.

Additionally, the polysaccharides which was found generally are less dangerous hazardous to normal cells than complete HK cells from the similar strain [147]. Wang et al. (2014) investigated L. plantarum to check the anti-cancer activity of c-EPS generated by it in vitro experiment and discovered that it greatly suppressed the growth of BGC-823, HepG-2, and most notably HT-29 tumor cells. The findings indicated that the c-EPS generated by L. plantarum 70810 could be used as functional foods and natural anticancer agents.

According to Clinicaltrials.gov, the other Lactobacillius species trials that are enlisted on the website are described below in the table 4: 
Table 4: Clinical trials of the application and effects of probiotic Lactobacillus spp against cancers

\begin{tabular}{|c|c|c|c|c|}
\hline $\begin{array}{c}\text { ClinicalTrials } \\
\text {.gov } \\
\text { Identifier }\end{array}$ & Types of Cancer & Topic & Dosage of Drug & Status \\
\hline NCT03940768 & Variety of Cancer & $\begin{array}{c}\text { In Treatment of Cancer Patients } \\
\text { Who Received Home Enteral } \\
\text { Nutrition }\end{array}$ & $\begin{array}{l}\text { Lactobacillus } \\
\text { plantarum } 299 \mathrm{v}\end{array}$ & Completed \\
\hline NCT01723592 & Breast Cancer & $\begin{array}{l}\text { Improve the Quality of the } \\
\text { Vaginal Flora of Women with } \\
\text { Breast Cancer and } \\
\text { Chemotherapy. }\end{array}$ & Mixed Probiotics & Completed \\
\hline NCT01370551 & Breast Cancer & $\begin{array}{l}\text { Study of Vaginal Lactobacilli } \\
\text { and Estriol (Gynoflor }{ }^{\circledR} \text { ) for } \\
\text { Atrophic Vaginitis in Breast } \\
\text { Cancer Patients (Gynoflor) }\end{array}$ & Gynoflor & Completed \\
\hline NCT01549782 & $\begin{array}{l}\text { Endometrial } \\
\text { Neoplasms }\end{array}$ & $\begin{array}{c}\text { Mixture of Prebiotics on } \\
\text { Intestinal Microbiota of Patients } \\
\text { Receiving Abdominal } \\
\text { Radiotherapy. }\end{array}$ & $\begin{array}{l}\text { Inulin and } \\
\text { Fructo-oligosacchari } \\
\text { de Maltodextrine }\end{array}$ & Completed \\
\hline NCT01036412 & $\begin{array}{l}\text { Head and Neck } \\
\text { Cancer }\end{array}$ & $\begin{array}{l}\text { Chlorhexidine Gel Therapy for } \\
\text { Cariogenic Oral Microflora }\end{array}$ & $\begin{array}{l}\text { 1\% Chlorhexidine } \\
\text { Gluconate Gel }\end{array}$ & Completed \\
\hline NCT03704727 & $\begin{array}{l}\text { Gastrointestinal } \\
\text { Irritation } \\
\text { Mucositis }\end{array}$ & $\begin{array}{l}\text { The Effects of Probiotics on } \\
\text { Intestinal Permeability in } \\
\text { Gastrointestinal Cancer Patients } \\
\text { in Chemotherapy }\end{array}$ & Mixed Probiotic & Completed \\
\hline NCT00768794 & Oral Candidiasis & $\begin{array}{l}\text { Acidophilus for the Treatment } \\
\text { and Prevention of Oral } \\
\text { Candidiasis in Patients } \\
\text { Undergoing Radiation Therapy }\end{array}$ & Acidophilus & Completed \\
\hline NCT01901042 & Prostate Cancer & $\begin{array}{l}\text { Efficacy of Symbiotic in the } \\
\text { Reduction of Acute Radiation } \\
\text { Proctitis Symptoms }\end{array}$ & $\begin{array}{l}\text { Dietary Supplement: } \\
\text { Symbiotic Dietary } \\
\text { Supplement: } \\
\text { Maltodextrin }\end{array}$ & Completed \\
\hline NCT03782428 & Colorectal Cancer & $\begin{array}{l}\text { An Evaluation of Probiotic in } \\
\text { the Clinical Course of Patients } \\
\text { with Colorectal Cancer }\end{array}$ & Probiotic & Completed \\
\hline NCT04229992 & Colorectal Cancer & $\begin{array}{l}\text { Calcium: Magnesium Balance, } \\
\text { Microbiota, and Necroptosis and } \\
\text { Inflammation }\end{array}$ & $\begin{array}{l}\text { Magnesium } \\
\text { glycinate }\end{array}$ & Completed \\
\hline NCT05109533 & $\begin{array}{l}\text { Vaginal Infection } \\
\text { HPV Infection }\end{array}$ & $\begin{array}{l}\text { Probiotics Role in HPV } \\
\text { Cervico-vaginal Infection } \\
\text { Clearance }\end{array}$ & $\begin{array}{l}\text { Lactobacillus } \\
\text { rhamnosus BMX } \\
\text { 54, Lactobacillus } \\
\text { reuteri RC-14, } \\
\text { Lactobacillus } \\
\text { rhamnosus GR-1 }\end{array}$ & Completed \\
\hline
\end{tabular}




\section{Bifidobacterium spp:}

Bifidobacterium species are another very well-known probiotics in the market for cancer treatment. Bifidobacteria, which are by nature occurring in the dominant colonic microbiota, account for up to twenty five percent of cultivable fecal bacteria in adults and up to $80 \%$ in newborns.

Bifidobacteria have been researched as probiotic agents because of its efficaciousness in preventing and treating a wide variety of gastrointestinal illnesses of humans or animal, including intestinal infections, colonic transit problems, colonic adenomas and cancer.The safe use of bifidobacteria is backed by a long history of fermented milk intake and developing information about the taxonomy and physiology of bifidobacteri [148]. Bacteria which produce lactic acid are generally found in food are classified as commensal bacteria with less or no pathogenic potential. A recent study of the safety of lactobacilli and bifidobacteri used as probiotics determined that they carry no danger to consumers' health [149-152]. The clinical trials which are registered on Clinicaltrials.gov are enlisted in the table no 5 below:

Table 5: Clinical trials of the application and effects of probiotic Bifidobacterium spp against cancers

\begin{tabular}{|c|c|c|c|c|}
\hline $\begin{array}{l}\text { ClinicalTrials.gov } \\
\text { Identifier }\end{array}$ & $\begin{array}{l}\text { Types of } \\
\text { Cancer }\end{array}$ & Topic & Dosage of Drug & Status \\
\hline NCT03072641 & Colon Cancer & $\begin{array}{l}\text { Using Probiotics to } \\
\text { Reactivate Tumor } \\
\text { Suppressor Genes in } \\
\text { Colon Cancer }\end{array}$ & $\begin{array}{c}\text { two ProBion Clinica tablets, } \\
\text { yielding a daily dose of } 1.4 \text { x } 10 \wedge \\
10 \text { Bifidobacterium lactis B1-04 } \\
(\text { ATCC SD5219), } 7 \times 10 \wedge 9 \\
\text { Lactobacillus acidophilus NCFM } \\
\text { (ATCC } 700396 \text { ), and } 0.63 \text { g inulin. }\end{array}$ & Completed \\
\hline NCT01549782 & $\begin{array}{l}\text { Endometrial } \\
\text { Neoplasms }\end{array}$ & $\begin{array}{l}\text { Mixture of Prebiotics } \\
\text { on Intestinal } \\
\text { Microbiota of } \\
\text { Patients Receiving } \\
\text { Abdominal } \\
\text { Radiotherapy. }\end{array}$ & $\begin{array}{l}\text { Dietary Supplement: Inulin and } \\
\text { Fructo-oligosaccharide Dietary } \\
\text { Supplement: Maltodextrine }\end{array}$ & Completed \\
\hline NCT03358511 & Breast Cancer & $\begin{array}{l}\text { Engineering Gut } \\
\text { Microbiome to } \\
\text { Target Breast Cancer }\end{array}$ & $\begin{array}{l}\text { Primal Defense Ultra }{ }^{\circledR} \text { Probiotic } \\
\text { Formula : Mixture of } 13 \text { species of } \\
\text { beneficial bacteria, including } \\
\text { Saccharomyces boulardii, } \\
\text { Lactobacillus plantarum, Bacillus } \\
\text { subtilis, Bifidobacterium lactis, } \\
\text { Bifidobacterium bifidum, } \\
\text { Lactobacillus rhamnosus, } \\
\text { Bifidobacterium breve, } \\
\text { lactobacillus casei, Lactobacillus } \\
\text { salivarius, Lactobacillus } \\
\text { acidophilus, Lactobacillus brevis, } \\
\text { Bifidobacterium longum, and } \\
\text { Lactobacillus paracasei. }\end{array}$ & Completed \\
\hline NCT03782428 & $\begin{array}{c}\text { Colorectal } \\
\text { Cancer }\end{array}$ & $\begin{array}{l}\text { An Evaluation of } \\
\text { Probiotic in the }\end{array}$ & $\begin{array}{l}\text { HEXIBO with } 107 \mathrm{mg} \text { of } \\
\text { Lactobacillus acidophilus BCMC® }\end{array}$ & Completed \\
\hline
\end{tabular}




\begin{tabular}{|c|c|c|c|c|}
\hline & & $\begin{array}{l}\text { Clinical Course of } \\
\text { Patients with } \\
\text { Colorectal Cancer }\end{array}$ & $\begin{array}{c}\text { 12130, Lactobacillus lactis } \\
\text { BCMC® 12451, Lactobacillus } \\
\text { casei subsp BCMC® } 12313 \text {, } \\
\text { Bifidobacterium longum BCMC® } \\
\text { 02120, Bifidobacterium bifidum } \\
\text { BCMC® } 02290 \text { and } \\
\text { Bifidobacterium infantis BCMC® } \\
02129\end{array}$ & \\
\hline NCT01839721 & $\begin{array}{c}\text { Cancer } \\
\text { Diarrhea } \\
\text { Abdominal } \\
\text { Pain Quality of } \\
\text { Life }\end{array}$ & $\begin{array}{l}\text { Impact of Probiotics } \\
\text { BIFILACT® on } \\
\text { Diarrhea in Patients } \\
\text { Treated with Pelvic } \\
\text { Radiation }\end{array}$ & $\begin{array}{c}\text { Impact of Probiotics BIFILACT® } \\
\text { on Diarrhea in Patients Treated } \\
\text { with Pelvic Radiation }\end{array}$ & Completed \\
\hline NCT01600781 & $\begin{array}{c}\text { Acute } \\
\text { Lymphocytic } \\
\text { Leukemia }\end{array}$ & $\begin{array}{c}\text { Effect of Oral } \\
\text { Supplementation } \\
\text { with a Fibre } \\
\text { Enriched Paediatric } \\
\text { Sip Feed for } \\
\text { Children with Acute } \\
\text { Lymphocytic } \\
\text { Leukemia }\end{array}$ & $\begin{array}{l}\text { NutriniDrink/Fortini MF } \\
\text { unflavoured }(1.5 \mathrm{kcal} / \mathrm{ml})\end{array}$ & Completed \\
\hline
\end{tabular}

\section{Probiotics enhancing the efficiency of Immunotherapy:}

Probiotics or good gut bacteria has the capability to boost the efficiency of the immunotherapy. In generally, all anticancer therapy can incorporate the effect of intestinal bacteria on the immune system.

The effects can be localized to the intestinal mucosa, because of stimulated dendritic cells traveling through the circulatory system [153]. Local resistance is induced via a variety of signaling pathways, including polysaccharide A, interleukin 10 (IL-10), and TLR [153]. Short Chain Fatty Acids generated by bacteria can also influence general immunity through IgA, contributing to improved immunity [154].

In contrary to the partial agonist, the distant effects of gut microbiota on immunity need a different mechanism dubbed the "cancer-immunity cycle," which relies on tumor antigen-activated $\mathrm{T}$ cells to recognize and kill tumor cells [155].

Additionally, there are connections between strains of gut microbiota and immune cell development. A segmented filamentous bacterium (SFB) can stimulate CD4+ T helper cell development as well as greater resistance to Citrobacter rodentium [156], while a Clostridium strain can contribute to CD4+ T regulatory cell differentiation [157]. Similarly, the gut microbiota can regulate dendritic cells via cytokine release, antigen presentation, and $\mathrm{T}$ cell activation [158].

Apart from its effect on the patient's initial immunological responses, it is believed that the makeup of the gut microbiota may influence the response to a variety of immunotherapies, including immune checkpoint 
inhibitors [158,159]. Anti-CTLA activity has been linked to Bacteroides, but anti-PD-L1 activity is Bifidobacterium-dependent [160]. Anti-CTLA therapy was not effective in germ-free or antibiotic-treated mice, however this scenario might be improved by orally feeding the mice with Bacteroides thetaiotaomicron, Bacteroides fragilis, or Burkholderia cepacia to promote dendritic cell and IL-12-dependent Th1 cell responses.

A few of the processes for the reinstatement of anti-CTLA activity is that Bifidobacterium may trigger immunoprotection via the TLR2/TLR4 signaling pathways. The spread of Bifidobacterium on the intestinal mucosa also contributes to the immunomodulatory effects of CTLA-4 antibody that are microbiota-dependent [159]. In 2019, 11 strains of bacteria isolated from the human gut were shown to be capable of facilitating immune checkpoint inhibitors by inducing IFN-+ CD8+ T cells. These strains include Parabacteroides spp., Alistipes senegalensis, five Bacteroides spp., Eubacterium limosum, Ruminococcaceae bacterium cv2, and Phascolarctobacterium faecium,[159].

Combined, these findings indicate that immunotherapy's immunostimulatory effect is highly dependent on the microbiota. Probiotics containing Lactobacillus and Bifidobacteria has been investigated on a latest trial where the combined medication was provided to post operative patients with colorectal cancer for half a year. The results has shown that the probiotics with combined strain has significantly down the expression of many pro-inflammatory cytokines, including TNF- $\alpha$, IL-6, IL-10, and IL-12, while maintaining the level of IFN-y. Oral probiotics containing Bifidobacterium could restore the antitumor impact of PD-L1 inhibition in mice with an unfavorable intestinal microbiota, mostly through enhancing dendritic cell maturation and thereby increasing the activity of tumor-specific CD8+ $T$ cells [160]. Similarly, a lower Firmicutes/Baxteroides ratio results in a lower tumorigenicity [161].

Investigating the processes, it is discovered that Bifidobacteria can affect the human immune system via the IFN- pathway [160]. Administering mice using probiotic Bifidobacteria, the number of MHC-II dendritic cells and tumor-specific T lymphocytes were increased within the tumor, owing to the released costimulatory molecules [161]. From the other hand, Bifidobacterium spp. can induce the transcription of up to 760 genes in tumor-infiltrating dendritic cells that are involved in antitumor responses, including Cd70 and Icam1 for CD8+ $\mathrm{T}$ cell activation, Relb for dendritic cell maturation, and Rab27a for antigen processing and cross presentation [160].

Apart from direct contact between bacteria and the immune system, probiotics can also work through the secretion of numerous probiotic-derived chemicals. Competence and sporulation factor (CSF), inorganic polyphosphates, ferrichrome, and a few additional peptides like as P75 and P40 have been demonstrated to have anticancer properties [75]. Such secreting compounds can exert their effects via a variety of distinct mechanisms and pathways. CSF is a quorum-sensing pentapeptide that can cause heat shock protein overexpression (Hsps). It furthermore activates the protein kinase B/Akt and p38 MAP kinase survival pathways in epithelial cells via organic cation transporter 2 (OCTN2). The production of Hsps can be stimulated by inorganic polyphosphates can and act on the integrin 1-p38 MAPK pathway, while the peptides P75 and P40 are related with activation of the Akt cell survival pathway. Ferrichrome, a molecule 
derived from the probiotic Lactobacillus casei, can act selectively on colon cancer cells to induce Caspase-3 and PARP cleavage and activation of the apoptotic pathway via the DDIT3-JNK signaling-mediated ER stress response pathway, exerting a therapeutic effect superior to cisplatin and 5-FU .

\section{Fecal Microbiota Transplantation (FMT):}

The application of FMT was done firstly to treat Clostridium difficile infection (CDI). Eiseman and colleagues have published the first case series describing this method for presumed severe CDI in the year of 1958, which involves transplanting useful bacteria from healthy humans into the gastrointestinal tracts of patients to rebuild the functional activity of good gut bacteria [166,167]. FMT was not associated with cancer treatment until 2012, when Neemann et al. demonstrated that by practicing it, a patient with acute lymphocytic leukemia (ALL) healed well from severe CDI generated by the immuno-suppressed state following allogeneic hematopoietic stem cell transplant [168].

Lately, this therapeutic method was used to a variety of other hematological malignancies, where an immune state and dysbiosis frequently developed as a post-operative consequence, resulting in C. difficile profusion and symptoms such as diarrhea, hematochezia and stomach discomfort [168,169]. Although clinical trials of FMT in cancer patients are still in their infancy, it has demonstrated its efficacy in the aid of a variety of complications connected with anticancer therapy, including CDI that is resistive to conventional medication [170], graft-versus-host disease following allogeneic stem cell transplantation [171], active ulcerative colitis $[173,174]$ and inflammatory bowel disease [172]. Moreever, post FMT problems such as bacteremia have been reported in some cases [168], and the mechanism remains unknown. Additional study is needed to determine the danger factors for FMT and to improve its safeness. In terms of anti-tumor therapy, preclinical research in mice indicated FMT's effectiveness in lowering colon carcinogenesis, while efficacy in clinical trials remains to be established [175].

Numerous experimental trials are presently in progress to examine the utilization of Fecal Microbiota Transplantation in cancer patients, along with the general aim of preventing and/or ameliorating intestinal adverse effects associated with anti-cancer therapy. Notwithstanding its success, FMT lacks control due to the fact that the entire bacteria are transplanted with the therapeutic bacterial species. As a result, it is critical to carefully monitor the donors' health and the composition of their gut microbiome [176].

According to Clinical trials website, the following listed experiment has been performed using FMT (Table 6)

Table 6: Effects of the application of Fecal Microbiota Transplantation against Cancers

\begin{tabular}{|c|c|c|c|c|}
\hline $\begin{array}{c}\text { Names of } \\
\text { Probiotic } \\
\text { strains }\end{array}$ & Cancer types & Study topic & $\begin{array}{c}\text { Drug } \\
\text { Administrated }\end{array}$ & Status of study \\
\hline NCT02770326 & $\begin{array}{l}\text { Various } \\
\text { Cancers }\end{array}$ & $\begin{array}{c}\text { Safety of stool transplant } \\
\text { for patients with difficult to } \\
\text { treat } C \text {. difficile infection }\end{array}$ & FMT & Active \\
\hline NCT02928523 & Acute Myeloid & $\begin{array}{c}\text { Prevention of dysbiosis } \\
\text { complications with }\end{array}$ & Autologous & Completed \\
\hline
\end{tabular}




\begin{tabular}{|c|c|c|c|c|}
\hline & Leukemia. & $\begin{array}{c}\text { autologous FMT in acute } \\
\text { myeloid leukemia patients } \\
\text { undergoing intensive } \\
\text { treatment (ODYSSEE) }\end{array}$ & FMT & Active \\
\hline NCT03353402 & Melanoma & $\begin{array}{c}\text { FMT in metastatic } \\
\text { melanoma patients who } \\
\text { failed immunotherapy }\end{array}$ & FMT & Active \\
\hline NCT03341143 & Melanoma & FMT in melanoma patients & $\begin{array}{c}\text { FMT with } \\
\text { Pembrolizumab }\end{array}$ & \\
\hline
\end{tabular}

\section{Fecal Microbiota Transplantation Verses Probiotics: who wins the race?}

It is not unknown that the variety of research trials with probiotics are of substandard, and that several data analysis remain conflicting or indeterminate. Hence, there is limited data regarding the effects of currently marketed probiotic products, that has given their widespread use, warrant additional research. Additionally, a recent comprehensive review [178,179] found that only two percent of randomized experimental trials with probiotics adequately disclosed critical safety elements. The trouble is exacerbated further by the variety of work preparation, inconsistent labeling and lot-to-lot variability, [180].

In comparison, FMT is classed as a controlled substance in the United States of America. This is true even in the case of autologous FMT. Currently, going through the FDA's enforcement discretion policy, C. difficile infections which cannot be recovered with antibiotics can be treated with FMT without agency permission. Nevertheless, this is a temporary measure until a viable pharmacological product to address the unmet need is approved. It is unknown if such a pharmaceutical product will be a defined FMT preparation or a microbial product. Additionally, if any microbial drug which is designated to treat a specific disease such as C. difficile infection, must have to go through numerous trials and it cannot be expected to be effective for the treatment of other illnesses, such as diabetes, inflammatory bowel disease, or autism. Therefore, the vast application of probiotics and its successful positive outcomes in cancer prevention treatment and in enhancing the efficiency of immunotherapy has made it to upholds a great future .

\section{The Multiple Delivery System of Probiotics to prevent cancer:}

Probiotic bacteria are crucial as transporters because of their broad permissiveness for the GI tract's environment combined with their inherent capacity to colonize the mucosal surface and keep their protective characteristics for an extended period of time [180]. The novel notion of "bio drug" is supported on the oral medication of genetically modified probiotics, that allows the therapeutic components to be distributed directly to the intestinal mucosa. Due to its low cost, simplicity of technology, and treatment technique, this plan of action has the prospective to be vastly employed in the prevention and treatment of a variety of illnesses.

Numerous research has demonstrated the potential for probiotic expression systems to be used as vaccines, stimulating the immune system (adaptive) response against pathogenic micro-organisms [180-185]. Various studies examining the implementation of genetically modified probiotics conveying the HPV E7 oncoprotein 
or the care of cervical cancer have demonstrated that, in contrast to conventional polyvalent vaccines, which have only precautionary characteristics against disease development, "probiotic vaccination" has been shown to have both protective and therapeutic effects such as stimulating immune response and tumor regression $[186,189]$. Pre-immunization with lactococci expressing the E7 gene considerably improved the anticancer impact of subsequent viral therapy [190].

Studies have shown that Lactobacillus lactis co-administration is capable to express oncoprotein E7 with immunostimulatory agents, such as interleukin-12, has been found to boost therapeutic impact in the TC-1 tumor mouse model $[187,188]$. Prophylactic vaccination of healthy persons gave opposition to future medication of fatal doses of tumor cell line TC-1, even after the second induction, resulting in a survival rate of 80 [168] to $100 \%$ [187]. Data shows that the administration of recombined probiotics for the treatment of tumor-bearing mice have resulted in visible tumor reduction, which was associated with an enhanced antitumor cytotoxic T lymphocyte (CTL) immune response [187,188].

Recent evidence suggests that probiotics could be used to deliver tumor-associated antigens (TAAs) as an orally administered vaccine, according to the success of a lately published strategy using Bifidobacterium expressing Wilms' tumor 1 (WT1) protein [191]. The presence of hypoxic and neurotic regions in solid cancer tissues provides an opportunity to exploit a particular probiotic strain's proclivity for selective localization and growth in anaerobic environments [192,197]. Such phenomena were subsequently examined in rodents, resulting in the assessment of through anticancer treatment employing Bifidobacteria as a delivery transport for specific medications such as angiostatins or cytosine deaminase $[198,199]$, as well as gene therapy [200]. The following table 7 illustrates the numerous delivery system of probiotics in cancer. 
Table 7: The prevention of cancer by using Probiotic strains with different therapy methods.

\begin{tabular}{|c|c|c|c|c|c|c|c|}
\hline $\begin{array}{l}\text { Names } \\
\text { of } \\
\text { Probioti } \\
\text { c strains }\end{array}$ & $\begin{array}{l}\text { Types of } \\
\text { Animal } \\
\text { Model }\end{array}$ & $\begin{array}{l}\text { Cancer Cell } \\
\text { line or Type }\end{array}$ & $\begin{array}{l}\text { Drug Delivery } \\
\text { System }\end{array}$ & $\begin{array}{l}\text { Thera } \\
\text { py } \\
\text { Types }\end{array}$ & Dosage & Results & $\begin{array}{l}\text { Reference } \\
\text { s }\end{array}$ \\
\hline $\begin{array}{l}\text { Bifidoba } \\
\text { cterium } \\
\text { infantis }\end{array}$ & $\begin{array}{l}\text { C57BL/6 } \\
\text { Mice, }\end{array}$ & $\begin{array}{l}\text { Skin } \\
\text { Melanoma }\end{array}$ & $\begin{array}{l}\text { Supernatant } \\
\text { fluid }\end{array}$ & $\begin{array}{l}\text { Gene } \\
\text { Thera } \\
\text { py }\end{array}$ & $\begin{array}{l}\text { Cytosine } \\
\text { deaminase/5-fl } \\
\text { uorocytosine }\end{array}$ & $\begin{array}{l}\text { After the experiment it } \\
\text { was observed that the } \\
\text { morphological changes } \\
\text { were increased and the } \\
\text { growth of tumor were } \\
\text { decreased. }\end{array}$ & 201 \\
\hline $\begin{array}{l}\text { Bifidoba } \\
\text { cterium } \\
\text { infantis }\end{array}$ & $\begin{array}{l}\text { C57BL/6 } \\
\text { Mice, }\end{array}$ & $\begin{array}{l}\text { Melanoma } \\
\text { B16-F10 cells } \\
\text { (Skin }\end{array}$ & Injection & $\begin{array}{l}\text { Gene } \\
\text { Thera } \\
\text { py }\end{array}$ & $\begin{array}{l}\text { Cytosine } \\
\text { deaminase/5-fl } \\
\text { uorocytosine }\end{array}$ & $\begin{array}{l}\text { Anti-tumor immunity } \\
\text { was observed. }\end{array}$ & 201 \\
\hline
\end{tabular}




\begin{tabular}{|c|c|c|c|c|c|c|c|}
\hline & & Melanoma) & & & & & \\
\hline $\begin{array}{l}\text { Bifidoba } \\
\text { cterium } \\
\text { infantis }\end{array}$ & $\begin{array}{l}\text { BALB/c } \\
\text { Mice }\end{array}$ & $\begin{array}{l}\text { colon } \\
\text { adenocarcino } \\
\text { ma gastric } \\
\text { cancer, liver } \\
\text { cancer, breast } \\
\text { cancer }\end{array}$ & Injection & $\begin{array}{l}\text { Gene } \\
\text { Thera } \\
\text { py }\end{array}$ & $\begin{array}{l}\text { Thymidine } \\
\text { kinase } \\
\text { (BF-rTK) } \\
\text { Ganciclovir } \\
\text { (GCV) }\end{array}$ & $\begin{array}{l}\text { Mitochondrial apoptosis } \\
\text { was observed to be } \\
\text { increased. On the other } \\
\text { hand the inflammation } \\
\text { was decreased so does } \\
\text { the TNF } \alpha \text {. }\end{array}$ & 200 \\
\hline $\begin{array}{l}\text { Lactococ } \\
\text { cus lactis }\end{array}$ & $\begin{array}{l}\mathrm{C} 57 \mathrm{BL} / 6 \\
\text { mice }\end{array}$ & $\begin{array}{l}\text { Human } \\
\text { papillomavirus } \\
\text { related cancer }\end{array}$ & Intranasal & $\begin{array}{l}\text { Vacci } \\
\text { nation }\end{array}$ & $\begin{array}{l}\text { E7 protein } \\
\text { displayed }\end{array}$ & $\begin{array}{l}\text { Antitumor effect of } \\
\text { following Ad-CRT-E7 } \\
\text { treatment was observed } \\
\text { to be decreased. }\end{array}$ & 190 \\
\hline $\begin{array}{l}\text { Lactococ } \\
\text { cus lactis }\end{array}$ & $\begin{array}{l}\text { C57BL/6 } \\
\text { mice }\end{array}$ & $\begin{array}{l}\text { Human } \\
\text { papillomavirus } \\
\text { related cancer }\end{array}$ & Intranasal & $\begin{array}{l}\text { Vacci } \\
\text { nation }\end{array}$ & $\begin{array}{l}\text { E7 protein } \\
\text { displayed }\end{array}$ & $\begin{array}{lr}\text { HPV-16 } & \text { E7-specific } \\
\text { immune } & \text { response was } \\
\text { seen. } & \end{array}$ & 189 \\
\hline $\begin{array}{l}\text { Bifidoba } \\
\text { cterium } \\
\text { longum }\end{array}$ & $\begin{array}{l}\text { C57BL/6N } \\
\text { mice }\end{array}$ & Leukemia & Oral & $\begin{array}{l}\text { Vacci } \\
\text { nation }\end{array}$ & $\begin{array}{l}\text { WT1 } \\
\text { displayed }\end{array}$ & $\begin{array}{l}\text { WT1(Leukemia)-express } \\
\text { ing Tumor growth } \\
\text { development was } \\
\text { decreased. Survival rate } \\
\text { was increased. Tumor } \\
\text { infiltration of CD4+ T } \\
\text { and CD8+ T was elevated } \\
\text { too and lastly the } \\
\text { increased level of } \\
\text { cytotoxic activity was } \\
\text { observed too. }\end{array}$ & 202 \\
\hline $\begin{array}{l}\text { Bifidoba } \\
\text { cterium } \\
\text { longum }\end{array}$ & $\begin{array}{l}\mathrm{BALB} / \mathrm{c} \\
\text { mice }\end{array}$ & $\begin{array}{l}\text { Colorectal } \\
\text { Cancer }\end{array}$ & $\begin{array}{ll}\text { Oral and } \\
\text { Injection }\end{array}$ & $\begin{array}{l}\text { Drug } \\
\text { Delive } \\
\text { ry }\end{array}$ & Tumstatin & $\begin{array}{l}\text { Antitumor effect was } \\
\text { observed. }\end{array}$ & 198 \\
\hline $\begin{array}{l}\text { Lactococ } \\
\text { cus lactis }\end{array}$ & Rats & $\begin{array}{l}\text { Colorectal } \\
\text { Cancer }\end{array}$ & Oral & $\begin{array}{l}\text { Drug } \\
\text { Delive } \\
\text { ry }\end{array}$ & Endostatin & $\begin{array}{lll}\text { Survival rate } & \text { was } \\
\text { increased } & & \end{array}$ & 203 \\
\hline
\end{tabular}




\begin{tabular}{|c|c|c|c|c|c|c|c|}
\hline $\begin{array}{l}\text { Bifidoba } \\
\text { cterium } \\
\text { longum }\end{array}$ & $\begin{array}{l}\text { C57BL/6 } \\
\text { mice }\end{array}$ & $\begin{array}{lr}\text { Lung } & \text { Cancer } \\
\text { and } & \text { Skin } \\
\text { Cancer } & \end{array}$ & Oral & $\begin{array}{l}\text { Drug } \\
\text { Delive } \\
\text { ry }\end{array}$ & $\begin{array}{l}\text { Endostatin or } \\
\text { endostatin }+ \text { se } \\
\text { lenium }\end{array}$ & $\begin{array}{l}\text { Endostatin treated group: } \\
\text { Tumor progression was } \\
\text { decreased and the } \\
\text { survival time was } \\
\text { increased } \\
\text { Endostatin } \pm \text { selenium:Tu } \\
\text { mor progression was } \\
\text { stopped and the activity } \\
\text { of natural killer cells and } \\
\text { T cells was increased and } \\
\text { also the activity of IL-2 } \\
\text { and TNF-a I was } \\
\text { increased too. }\end{array}$ & 199 \\
\hline
\end{tabular}

\section{Conclusion:}

The co-relation between cancer and gastrointestinal microbiota has deep insights. The gastrointestinal bacteria of human body secrete numerous metabolites and study of these metabolites on human immune system is very important as it uphold the answer to cure many inflammatory diseases such as cancer. The gut bacteria can have a significant impact on the development and tumorigenesis, as well as on the result of chemo- and immunotherapies.

Immunosurveillance, mediates most of the side effects and they may also be mediated directly by products secreted by microbes — such as cytotoxic agents, carcinogens, and metabolites — on cancer cells via a variety of mechanisms. These may include mutagenesis, epigenetic modification, activation of host cell receptors, and manipulation of anabolic and catabolic pathways.

The manipulated gut bacteria or Probiotics have prominent anti-cancer immunity against cancer. As we know that carcinogenesis is known to be the dangerous non-curable disease and it causes the most mortality worldwide. Researchers has been working for decades to defeat this lethal disease. While the current anticancer medicines have demonstrated efficacy in providing palliative or curative therapy, there are still various advert impacts associated with this procedure, resulting in decreased efficacy and prognosis. Together with all studies, data on the function and effect of microbiota in cancer have revealed this subject as a potentially prominent mediator of response to cancer treatment with the advancing technology and research on the human gastrointestinal microbiota, we now know that the gastrointestinal microbiota and the host have a close symbiotic relationship. Disturbances in the structure of the gastrointestinal microbiota can be noticed in the environment of a variety of digestive system illnesses. To see if an instability in the gut microbiota the source is or consequence of disease, it may accelerate disease development and also control 
the related treatment methods. Additionally, it is established that by altering the gut microbiome, such as by administering helpful bacteria strains as probiotics, the response to cancer treatment can be boosted. Microorganisms' probiotic qualities are a strain feature. There is a increasing wealth of data suggesting probiotics can aid to prevent cancer and enhance anti-cancer therapy. Numerous positive results have been discovered as a result of laboratory study, indicating that probiotics have an anticancer effect. Therefore, the data reported in this review article confirms the efficacy of probiotics to prevent malignant neoplastic disease or as adjunct therapy during anticancer immunotherapy. Clinical investigations are yet insufficient to conclusively demonstrate the efficacy of probiotic bacteria in this area. As a result, it is critical and in demand to continue research into the anti-cancer characteristics and mechanisms of action of specific probiotic strains. Furthermore, it is extremely mandatory to study more about the probiotics and its characteristics and metabolites to conquer the cancer with the anti-cancer immunity of gut bacteria. 


\section{Reference:}

1. Roy, S.; Trinchieri, G. Microbiota: A Key Orchestrator of Cancer Therapy. Nat. Rev. Cancer 2017, 17 (5), 271-285. https://doi.org/10.1038/nrc.2017.13.

2. Gori, S.; Inno, A.; Belluomini, L.; Bocus, P.; Bisoffi, Z.; Russo, A.; Arcaro, G. Gut Microbiota and Cancer: How Gut Microbiota Modulates Activity, Efficacy and Toxicity of Antitumoral Therapy. Crit. Rev. Oncol. Hematol. 2019, 143, 139-147. https://doi.org/10.1016/j.critrevonc.2019.09.003.

3. AlHilli, M. M.; Bae-Jump, V. Diet and Gut Microbiome Interactions in Gynecologic Cancer. Gynecol. Oncol. 2020, 159 (2), 299-308. https://doi.org/10.1016/j.ygyno.2020.08.027.

4. Rodríguez, J. M.; Murphy, K.; Stanton, C.; Ross, R. P.; Kober, O. I.; Juge, N.; Avershina, E.; Rudi, K.; Narbad, A.; Jenmalm, M. C.; Marchesi, J. R.; Collado, M. C. The Composition of the Gut Microbiota throughout Life, with an Emphasis on Early Life. Microb. Ecol. Health Dis. 2015, 26 (0), 26050. https://doi.org/10.3402/mehd.v26.26050.

5. Frank, D. N.; St Amand, A. L.; Feldman, R. A.; Boedeker, E. C.; Harpaz, N.; Pace, N. R. Molecular-Phylogenetic Characterization of Microbial Community Imbalances in Human Inflammatory Bowel Diseases. Proc. Natl. Acad. Sci. U. S. A. 2007, 104 (34), 13780-13785. https://doi.org/10.1073/pnas.0706625104.

6. Wen, L.; Ley, R. E.; Volchkov, P. Y.; Stranges, P. B.; Avanesyan, L.; Stonebraker, A. C.; Hu, C.; Wong, F. S.; Szot, G. L.; Bluestone, J. A.; Gordon, J. I.; Chervonsky, A. V. Innate Immunity and Intestinal Microbiota in the Development of Type 1 Diabetes. Nature 2008, 455 (7216), 1109-1113. https://doi.org/10.1038/nature07336.

7. Ley, R. E.; Turnbaugh, P. J.; Klein, S.; Gordon, J. I. Microbial Ecology: Human Gut Microbes Associated with Obesity. Nature 2006, 444 (7122), 1022-1023. https://doi.org/10.1038/4441022a.

8. Hsiao, E. Y.; McBride, S. W.; Hsien, S.; Sharon, G.; Hyde, E. R.; McCue, T.; Codelli, J. A.; Chow, J.; Reisman, S. E.; Petrosino, J. F.; Patterson, P. H.; Mazmanian, S. K. Microbiota Modulate Behavioral and Physiological Abnormalities Associated with Neurodevelopmental Disorders. Cell 2013, 155 (7), 1451-1463. https://doi.org/10.1016/j.cell.2013.11.024.

9. Valles-Colomer, M.; Falony, G.; Darzi, Y.; Tigchelaar, E. F.; Wang, J.; Tito, R. Y.; Schiweck, C.; Kurilshikov, A.; Joossens, M.; Wijmenga, C.; Claes, S.; Van Oudenhove, L.; Zhernakova, A.; Vieira-Silva, S.; Raes, J. The Neuroactive Potential of the Human Gut Microbiota in Quality of Life and Depression. Nat. Microbiol. 2019, 4 (4), 623-632. https://doi.org/10.1038/s41564-018-0337-X.

10. Kostic, A. D.; Gevers, D.; Pedamallu, C. S.; Michaud, M.; Duke, F.; Earl, A. M.; Ojesina, A. I.; Jung, J.; Bass, A. J.; Tabernero, J.; Baselga, J.; Liu, C.; Shivdasani, R. A.; Ogino, S.; Birren, B. W.; Huttenhower, C.; Garrett, W. S.; Meyerson, M. Genomic Analysis Identifies Association of Fusobacterium with Colorectal Carcinoma. Genome Res. 2012, 22 (2), 292-298. https://doi.org/10.1101/gr.126573.111.

11. Allen-Vercoe, E.; Jobin, C. Fusobacterium and Enterobacteriaceae: Important Players for CRC? Immunol. Lett. 2014, 162 (2 Pt A), 54-61. https://doi.org/10.1016/j.imlet.2014.05.014.

12. Levy, M.; Thaiss, C. A.; Elinav, E. Metabolites: Messengers between the Microbiota and the Immune System. Genes Dev. 2016, 30 (14), 1589-1597. https://doi.org/10.1101/gad.284091.116. 
13. White, J. R.; Dauros-Singorenko, P.; Hong, J.; Vanholsbeeck, F.; Phillips, A.; Swift, S. The Role of Host Molecules in Communication with the Resident and Pathogenic Microbiota: A Review. Medicine in Microecology 2020, 4 (100005), 100005. https://doi.org/10.1016/j.medmic.2020.100005.

14. Kroemer, G.; Zitvogel, L. Cancer Immunotherapy in 2017: The Breakthrough of the Microbiota. Nat. Rev. Immunol. 2018, 18 (2), 87-88. https://doi.org/10.1038/nri.2018.4.

15. Geva-Zatorsky, N.; Sefik, E.; Kua, L.; Pasman, L.; Tan, T. G.; Ortiz-Lopez, A.; Yanortsang, T. B.; Yang, L.; Jupp, R.; Mathis, D.; Benoist, C.; Kasper, D. L. Mining the Human Gut Microbiota for $\begin{array}{llllll}\text { Immunomodulatory } \quad \text { Organisms. } & \text { Cell } & \mathbf{2 0 1 7}, & 168 & \text { (5), }\end{array}$ https://doi.org/10.1016/j.cell.2017.01.022.

16. Haber, A. L.; Biton, M.; Rogel, N.; Herbst, R. H.; Shekhar, K.; Smillie, C.; Burgin, G.; Delorey, T. M.; Howitt, M. R.; Katz, Y.; Tirosh, I.; Beyaz, S.; Dionne, D.; Zhang, M.; Raychowdhury, R.; Garrett, W. S.; Rozenblatt-Rosen, O.; Shi, H. N.; Yilmaz, O.; Xavier, R. J.; Regev, A. A Single-Cell Survey of the Small Intestinal Epithelium. Nature 2017, 551 (7680), 333-339. https://doi.org/10.1038/nature24489.

17. Rothschild, D.; Weissbrod, O.; Barkan, E.; Kurilshikov, A.; Korem, T.; Zeevi, D.; Costea, P. I.; Godneva, A.; Kalka, I. N.; Bar, N.; Shilo, S.; Lador, D.; Vila, A. V.; Zmora, N.; Pevsner-Fischer, M.; Israeli, D.; Kosower, N.; Malka, G.; Wolf, B. C.; Avnit-Sagi, T.; Lotan-Pompan, M.; Weinberger, A.; Halpern, Z.; Carmi, S.; Fu, J.; Wijmenga, C.; Zhernakova, A.; Elinav, E.; Segal, E. Environment Dominates over Host Genetics in Shaping Human Gut Microbiota. Nature 2018, 555 (7695), $210-215$. https://doi.org/10.1038/nature25973.

18. Korem, T.; Zeevi, D.; Suez, J.; Weinberger, A.; Avnit-Sagi, T.; Pompan-Lotan, M.; Matot, E.; Jona, G.; Harmelin, A.; Cohen, N.; Sirota-Madi, A.; Thaiss, C. A.; Pevsner-Fischer, M.; Sorek, R.; Xavier, R. J.; Elinav, E.; Segal, E. Growth Dynamics of Gut Microbiota in Health and Disease Inferred from Single Metagenomic Samples. Science 2015, 349 (6252), 1101-1106. https://doi.org/10.1126/science.aac4812.

19. Gopalakrishnan, V.; Helmink, B. A.; Spencer, C. N.; Reuben, A.; Wargo, J. A. The Influence of the Gut Microbiome on Cancer, Immunity, and Cancer Immunotherapy. Cancer Cell 2018, 33 (4), 570-580. https://doi.org/10.1016/j.ccell.2018.03.015.

20. Goodman, B.; Gardner, H. The Microbiome and Cancer: The Microbiome and Cancer. J. Pathol. 2018, 244 (5), 667-676. https://doi.org/10.1002/path.5047.

21. Knight, R.; Callewaert, C.; Marotz, C.; Hyde, E. R.; Debelius, J. W.; McDonald, D.; Sogin, M. L. The Microbiome and Human Biology. Annu. Rev. Genomics Hum. Genet. 2017, 18 (1), $65-86$. https://doi.org/10.1146/annurev-genom-083115-022438.

22. Fulbright, L. E.; Ellermann, M.; Arthur, J. C. The Microbiome and the Hallmarks of Cancer. PLoS Pathog. 2017, 13 (9), e1006480. https://doi.org/10.1371/journal.ppat.1006480.

23. Gagnaire, A.; Nadel, B.; Raoult, D.; Neefjes, J.; Gorvel, J.-P. Collateral Damage: Insights into Bacterial Mechanisms That Predispose Host Cells to Cancer. Nat. Rev. Microbiol. 2017, 15 (2), $109-128$. https://doi.org/10.1038/nrmicro.2016.171.

24. Carabotti, M.; Scirocco, A.; Maselli, M. A.; Severi, C. The Gut-Brain Axis: Interactions between Enteric Microbiota, Central and Enteric Nervous Systems. Ann. Gastroenterol. 2015, 28 (2), $203-209$. 
25. Rossi, P.; Difrancia, R.; Quagliariello, V.; Savino, E.; Tralongo, P.; Randazzo, C. L.; Berretta, M. B-Glucans from Grifola Frondosa and Ganoderma Lucidum in Breast Cancer: An Example of Complementary and Integrative Medicine. Oncotarget 2018, 9 (37), 24837-24856. https://doi.org/10.18632/oncotarget.24984.

26. Tropini, C.; Earle, K. A.; Huang, K. C.; Sonnenburg, J. L. The Gut Microbiome: Connecting Spatial Organization to Function. Cell Host Microbe 2017, 21 (4), 433-442. https://doi.org/10.1016/j.chom.2017.03.010.

27. Valarmathi, T.; Premkumar, R.; Milton Franklin Benial, A. Spectroscopic and molecular docking studies on 1-Hydroxyanthraquinone: A potent ovarian cancer drug. J. Mol. Struct. 2020, 1213, 128163.

28. Friedman, E. S.; Bittinger, K.; Esipova, T. V.; Hou, L.; Chau, L.; Jiang, J.; Mesaros, C.; Lund, P. J.; Liang, X.; FitzGerald, G. A.; Goulian, M.; Lee, D.; Garcia, B. A.; Blair, I. A.; Vinogradov, S. A.; Wu, G. D. Microbes vs. Chemistry in the Origin of the Anaerobic Gut Lumen. Proc. Natl. Acad. Sci. U. S. A. 2018, 115 (16), 4170-4175. https://doi.org/10.1073/pnas.1718635115.

29. Martinez-Guryn, K.; Leone, V.; Chang, E. B. Regional Diversity of the Gastrointestinal Microbiome. Cell Host Microbe 2019, 26 (3), 314-324. https://doi.org/10.1016/j.chom.2019.08.011.

30. Allegra, A.; Musolino, C.; Tonacci, A.; Pioggia, G.; Gangemi, S. Interactions between the MicroRNAs and Microbiota in Cancer Development: Roles and Therapeutic Opportunities. Cancers (Basel) 2020, 12 (4), 805. https://doi.org/10.3390/cancers12040805.

31. Lu, K.; Mahbub, R.; Fox, J. G. Xenobiotics: Interaction with the Intestinal Microflora. ILAR J. 2015, 56 (2), 218-227. https://doi.org/10.1093/ilar/ilv018.

32. Chen, P.; Chen, X.; Hao, L.; Du, P.; Li, C.; Han, H.; Xu, H.; Liu, L. The Bioavailability of Soybean Polysaccharides and Their Metabolites on Gut Microbiota in the Simulator of the Human Intestinal Microbial Ecosystem (SHIME). Food Chem. 2021, $362 \quad$ (130233), 130233. https://doi.org/10.1016/j.foodchem.2021.130233.

33. van der Hee, B.; Wells, J. M. Microbial Regulation of Host Physiology by Short-Chain Fatty Acids. Trends Microbiol. 2021, 29 (8), 700-712. https://doi.org/10.1016/j.tim.2021.02.001.

34. Hooks, K. B.; O’Malley, M. A. Dysbiosis and Its Discontents. MBio 2017, 8 (5). https://doi.org/10.1128/mBio.01492-17

35. Toor, D.; Wsson, M. K.; Kumar, P.; Karthikeyan, G.; Kaushik, N. K.; Goel, C.; Singh, S.; Kumar, A.; Prakash, H. Dysbiosis Disrupts Gut Immune Homeostasis and Promotes Gastric Diseases. Int. J. Mol. Sci. 2019, 20 (10), 2432. https://doi.org/10.3390/ijms20102432.

36. Ahmed, I.; Roy, B. C.; Khan, S. A.; Septer, S.; Umar, S. Microbiome, Metabolome and Inflammatory Bowel Disease. Microorganisms 2016, 4 (2), 20. https://doi.org/10.3390/microorganisms4020020.

37. Bergot, A.-S.; Giri, R.; Thomas, R. The Microbiome and Rheumatoid Arthritis. Best Pract. Res. Clin. Rheumatol. 2019, 33 (6), 101497. https://doi.org/10.1016/j.berh.2020.101497.

38. Han, H.; Li, Y.; Fang, J.; Liu, G.; Yin, J.; Li, T.; Yin, Y. Gut Microbiota and Type 1 Diabetes. Int. J. Mol. Sci. 2018, 19 (4). https://doi.org/10.3390/ijms19040995. 
39. Mirza, A.; Mao-Draayer, Y. The Gut Microbiome and Microbial Translocation in Multiple Sclerosis. Clin. Immunol. 2017, 183, 213-224. https://doi.org/10.1016/j.clim.2017.03.001.

40. Katz-Agranov, N.; Zandman-Goddard, G. The Microbiome and Systemic Lupus Erythematosus. Immunol. Res. 2017, 65 (2), 432-437. https://doi.org/10.1007/s12026-017-8906-2.

41. Schwabe, R. F.; Jobin, C. The Microbiome and Cancer. Nat. Rev. Cancer 2013, 13 (11), 800-812. https://doi.org/10.1038/nrc3610.

42. Kamada, N.; Seo, S.-U.; Chen, G. Y.; Núñez, G. Role of the Gut Microbiota in Immunity and Inflammatory Disease. Nat. Rev. Immunol. 2013, 13 (5), 321-335. https://doi.org/10.1038/nri3430.

43. Wang, J.-L.; Chang, C.-H.; Lin, J.-W.; Wu, L.-C.; Chuang, L.-M.; Lai, M.-S. Infection, Antibiotic Therapy and Risk of Colorectal Cancer: A Nationwide Nested Case-Control Study in Patients with Type 2 Diabetes Mellitus: Infection, Antibiotics and Colon Cancer. Int. J. Cancer 2014, 135 (4), 956-967. https://doi.org/10.1002/ijc.28738.

44. Bonnet, M.; Buc, E.; Sauvanet, P.; Darcha, C.; Dubois, D.; Pereira, B.; Déchelotte, P.; Bonnet, R.; Pezet, D.; Darfeuille-Michaud, A. Colonization of the Human Gut by E. Coli and Colorectal Cancer Risk. Clin. Cancer Res. 2014, 20 (4), 859-867. https://doi.org/10.1158/1078-0432.CCR-13-1343.

45. Valarmathi, T.; Premkumar, R.; Meera, M.R; Milton Franklin Benial,

A. Spectroscopic, Quantum Chemical and Molecular Docking Studies on 1-Amino-5-chloroanthraquinone: A Targeted Drug Therapy for Thyroid Cancer. Spectrochim. Acta 2021, 255(3), 119659.

46. Arthur, J. C.; Perez-Chanona, E.; Mühlbauer, M.; Tomkovich, S.; Uronis, J. M.; Fan, T.-J.; Campbell, B. J.; Abujamel, T.; Dogan, B.; Rogers, A. B.; Rhodes, J. M.; Stintzi, A.; Simpson, K. W.; Hansen, J. J.; Keku, T. O.; Fodor, A. A.; Jobin, C. Intestinal Inflammation Targets Cancer-Inducing Activity of the Microbiota. Science 2012, 338 (6103), 120-123. https://doi.org/10.1126/science.1224820.

47. Zhan, Y.; Chen, P.-J.; Sadler, W. D.; Wang, F.; Poe, S.; Núñez, G.; Eaton, K. A.; Chen, G. Y. Gut Microbiota Protects against Gastrointestinal Tumorigenesis Caused by Epithelial Injury. Cancer Res. 2013, 73 (24), 7199-7210. https://doi.org/10.1158/0008-5472.CAN-13-0827.

48. Louis, P.; Hold, G. L.; Flint, H. J. The Gut Microbiota, Bacterial Metabolites and Colorectal Cancer. Nat. Rev. Microbiol. 2014, 12 (10), 661-672. https://doi.org/10.1038/nrmicro3344.

49. Yoshimoto, S.; Loo, T. M.; Atarashi, K.; Kanda, H.; Sato, S.; Oyadomari, S.; Iwakura, Y.; Oshima, K.; Morita, H.; Hattori, M.; Honda, K.; Ishikawa, Y.; Hara, E.; Ohtani, N. Obesity-Induced Gut Microbial Metabolite Promotes Liver Cancer through Senescence Secretome. Nature 2013, 499 (7456), 97-101. https://doi.org/10.1038/nature12347.

50. Dapito, D. H.; Mencin, A.; Gwak, G.-Y.; Pradere, J.-P.; Jang, M.-K.; Mederacke, I.; Caviglia, J. M.; Khiabanian, H.; Adeyemi, A.; Bataller, R.; Lefkowitch, J. H.; Bower, M.; Friedman, R.; Sartor, R. B.; Rabadan, R.; Schwabe, R. F. Promotion of Hepatocellular Carcinoma by the Intestinal Microbiota and TLR4. Cancer Cell 2012, 21 (4), 504-516. https://doi.org/10.1016/j.ccr.2012.02.007.

51. Xuan, C.; Shamonki, J. M.; Chung, A.; Dinome, M. L.; Chung, M.; Sieling, P. A.; Lee, D. J. Microbial Dysbiosis Is Associated with Human Breast Cancer. PLoS One 2014, 9 (1), e83744. 
https://doi.org/10.1371/journal.pone.0083744.

52. Velicer, C. M.; Heckbert, S. R.; Lampe, J. W.; Potter, J. D.; Robertson, C. A.; Taplin, S. H. Antibiotic Use in Relation to the Risk of Breast Cancer. JAMA 2004, 291 (7), 827-835. https://doi.org/10.1001/jama.291.7.827.

53. Dejea, C.; Wick, E.; Sears, C. L. Bacterial Oncogenesis in the Colon. Future Microbiol. 2013, 8 (4), 445-460. https://doi.org/10.2217/fmb.13.17.

54. Tsvetikova, S. A.; Koshel, E. I. Microbiota and Cancer: Host Cellular Mechanisms Activated by Gut Microbial Metabolites. Int. J. Med. Microbiol. 2020, $310 \quad$ (4), 151425. https://doi.org/10.1016/j.ijmm.2020.151425.

55. Hatakeyama, M. Structure and Function of Helicobacter Pylori CagA, the First-Identified Bacterial Protein Involved in Human Cancer. Proc. Jpn. Acad. Ser. B Phys. Biol. Sci. 2017, 93 (4), 196-219. https://doi.org/10.2183/pjab.93.013.

56. Goodwin, A. C.; Destefano Shields, C. E.; Wu, S.; Huso, D. L.; Wu, X.; Murray-Stewart, T. R.; Hacker-Prietz, A.; Rabizadeh, S.; Woster, P. M.; Sears, C. L.; Casero, R. A., Jr. Polyamine Catabolism Contributes to Enterotoxigenic Bacteroides Fragilis-Induced Colon Tumorigenesis. Proc. Natl. Acad. Sci. U. S. A. 2011, 108 (37), 15354-15359. https://doi.org/10.1073/pnas.1010203108.

57. Raza, M. H.; Gul, K.; Arshad, A.; Riaz, N.; Waheed, U.; Rauf, A.; Aldakheel, F.; Alduraywish, S.; Rehman, M. U.; Abdullah, M.; Arshad, M. Microbiota in Cancer Development and Treatment. $J$. Cancer Res. Clin. Oncol. 2019, 145 (1), 49-63. https://doi.org/10.1007/s00432-018-2816-0.

58. Plottel, C. S.; Blaser, M. J. Microbiome and Malignancy. Cell Host Microbe 2011, 10 (4), 324-335. https://doi.org/10.1016/j.chom.2011.10.003.

59. Doisneau-Sixou, S. F.; Sergio, C. M.; Carroll, J. S.; Hui, R.; Musgrove, E. A.; Sutherland, R. L. Estrogen and Antiestrogen Regulation of Cell Cycle Progression in Breast Cancer Cells. Endocr. Relat. Cancer 2003, 179-186. https://doi.org/10.1677/erc.0.0100179.

60. Fernández, M.; Reina-Pérez, I.; Astorga, J.; Rodríguez-Carrillo, A.; Plaza-Díaz, J.; Fontana, L. Breast Cancer and Its Relationship with the Microbiota. Int. J. Environ. Res. Public Health 2018, 15 (8), 1747. https://doi.org/10.3390/ijerph15081747.

61. Kilkkinen, A.; Rissanen, H.; Klaukka, T.; Pukkala, E.; Heliövaara, M.; Huovinen, P.; Männistö, S.; Aromaa, A.; Knekt, P. Antibiotic Use Predicts an Increased Risk of Cancer. Int. J. Cancer 2008, 123 (9), 2152-2155. https://doi.org/10.1002/ijc.23622.

62. Conlon, M.; Bird, A. The Impact of Diet and Lifestyle on Gut Microbiota and Human Health. Nutrients 2014, 7 (1), 17-44. https://doi.org/10.3390/nu7010017.

63. Fiehn, O. Metabolomics-The Link between Genotypes and Phenotypes. Plant Molecular Biology 2002, $48(1-2), 155-171$.

64. Aguiar-Pulido, V.; Huang, W.; Suarez-Ulloa, V.; Cickovski, T.; Mathee, K.; Narasimhan, G. Metagenomics, Metatranscriptomics, and Metabolomics Approaches for Microbiome Analysis: Supplementary Issue: Bioinformatics Methods and Applications for Big Metagenomics Data. Evol. Bioinform. Online 2016, 12 (Suppl 1), 5-16. https://doi.org/10.4137/EBO.S36436. 
65. Vernocchi, P.; Del Chierico, F.; Putignani, L. Gut Microbiota Profiling: Metabolomics Based Approach to Unravel Compounds Affecting Human Health. Front. Microbiol. 2016, 7, 1144. https://doi.org/10.3389/fmicb.2016.01144.

66. Kumar, R.; Eipers, P.; Little, R. B.; Crowley, M.; Crossman, D. K.; Lefkowitz, E. J.; Morrow, C. D. Getting Started with Microbiome Analysis: Sample Acquisition to Bioinformatics. Curr. Protoc. Hum. Genet. 2014, 82 (1), 18.8.1-29. https://doi.org/10.1002/0471142905.hg1808s82.

67. Koyambo-Konzapa, S-J.; Mbesse Kongbonga G.Y.; Premkumar, R.; Duvalier Ramlina Vamhindi, B.S.; Nsangou, M.; Milton Franklin Benial, A. Spectroscopic, quantum chemical, molecular docking and molecular dynamics investigations of hydroxylic indole-3-pyruvic acid: a potent candidate for nonlinear optical applications and Alzheimer's drug. J. Biomol. Struct. Dyn. 2021, $\underline{10.1080 / 07391102.2021 .1947380}$

68. Aldridge, B. B.; Rhee, K. Y. Microbial Metabolomics: Innovation, Application, Insight. Curr. Opin. Microbiol. 2014, 19, 90-96. https://doi.org/10.1016/j.mib.2014.06.009.

69. Jan, G.; Belzacq, A.-S.; Haouzi, D.; Rouault, A.; Métivier, D.; Kroemer, G.; Brenner, C. Propionibacteria Induce Apoptosis of Colorectal Carcinoma Cells via Short-Chain Fatty Acids Acting on Mitochondria. Cell Death Differ. 2002, 9 (2), 179-188. https://doi.org/10.1038/sj.cdd.4400935.

70. Wei, W.; Sun, W.; Yu, S.; Yang, Y.; Ai, L. Butyrate Production from High-Fiber Diet Protects against Lymphoma Tumor. Leuk. Lymphoma $\mathbf{2 0 1 6 ,} 57 \quad$ (10), 2401-2408. https://doi.org/10.3109/10428194.2016.1144879.

71. Paulos, C. M.; Wrzesinski, C.; Kaiser, A.; Hinrichs, C. S.; Chieppa, M.; Cassard, L.; Palmer, D. C.; Boni, A.; Muranski, P.; Yu, Z.; Gattinoni, L.; Antony, P. A.; Rosenberg, S. A.; Restifo, N. P. Microbial Translocation Augments the Function of Adoptively Transferred Self/Tumor-Specific CD8+ T Cells via TLR4 Signaling. J. Clin. Invest. 2007, 117 (8), 2197-2204. https://doi.org/10.1172/JCI32205.

72. Paavonen, J.; Naud, P.; Salmerón, J.; Wheeler, C. M.; Chow, S.-N.; Apter, D.; Kitchener, H.; Castellsague, X.; Teixeira, J. C.; Skinner, S. R.; Hedrick, J.; Jaisamrarn, U.; Limson, G.; Garland, S.; Szarewski, A.; Romanowski, B.; Aoki, F. Y.; Schwarz, T. F.; Poppe, W. A. J.; Bosch, F. X.; Jenkins, D.; Hardt, K.; Zahaf, T.; Descamps, D.; Struyf, F.; Lehtinen, M.; Dubin, G.; HPV PATRICIA Study Group. Efficacy of Human Papillomavirus (HPV)-16/18 AS04-Adjuvanted Vaccine against Cervical Infection and Precancer Caused by Oncogenic HPV Types (PATRICIA): Final Analysis of a Double-Blind, Randomised Study in Young Women. Lancet 2009, 374 (9686), 301-314. https://doi.org/10.1016/S0140-6736(09)61248-4.

73. Aranda, F.; Bloy, N.; Pesquet, J.; Petit, B.; Chaba, K.; Sauvat, A.; Kepp, O.; Khadra, N.; Enot, D.; Pfirschke, C.; Pittet, M.; Zitvogel, L.; Kroemer, G.; Senovilla, L. Immune-Dependent Antineoplastic Effects of Cisplatin plus Pyridoxine in Non-Small-Cell Lung Cancer. Oncogene 2015, 34 (23), 30533062. https://doi.org/10.1038/onc.2014.234

74. Dembiński, A.; Warzecha, Z.; Ceranowicz, P.; Dembiński, M.; Cieszkowski, J.; Gosiewski, T.; Bulanda, M.; Kuśnierz-Cabala, B.; Gałązka, K.; Konturek, P. C. Synergic Interaction of Rifaximin and Mutaflor (Escherichia Coli Nissle 1917) in the Treatment of Acetic Acid-Induced Colitis in Rats. 
Gastroenterol. Res. Pract. 2016, 2016, 3126280. https://doi.org/10.1155/2016/3126280.

75. Konishi, H.; Fujiya, M.; Tanaka, H.; Ueno, N.; Moriichi, K.; Sasajima, J.; Ikuta, K.; Akutsu, H.; Tanabe, H.; Kohgo, Y. Probiotic-Derived Ferrichrome Inhibits Colon Cancer Progression via JNK-Mediated Apoptosis. Nat. Commun. 2016, 7 (1), 12365. https://doi.org/10.1038/ncomms12365.

76. Lenoir, M.; Del Carmen, S.; Cortes-Perez, N. G.; Lozano-Ojalvo, D.; Muñoz-Provencio, D.; Chain, F.; Langella, P.; de Moreno de LeBlanc, A.; LeBlanc, J. G.; Bermúdez-Humarán, L. G. Lactobacillus Casei BL23 Regulates Treg and Th17 T-Cell Populations and Reduces DMH-Associated Colorectal Cancer. J. Gastroenterol. 2016, 51 (9), 862-873. https://doi.org/10.1007/s00535-015-1158-9.

77. Lee, J.-W.; Shin, J.-G.; Kim, E. H.; Kang, H. E.; Yim, I. B.; Kim, J. Y.; Joo, H.-G.; Woo, H. J. Immunomodulatory and Antitumor Effects in Vivo by the Cytoplasmic Fraction of Lactobacillus Casei and Bifidobacterium Longum. J. Vet. Sci. 2004, 5 (1), 41-48. https://doi.org/10.4142/jvs.2004.5.1.41.

78. Baldwin*, C.; Millette*, M.; Oth †, D.; Ruiz, M. T.; Luquet, F.-M.; Lacroix, M. ProbioticLactobacillus AcidophilusandL. CaseiMix Sensitize Colorectal Tumoral Cells to 5-Fluorouracil-Induced Apoptosis. Nutr. Cancer 2010, 62 (3), 371-378. https://doi.org/10.1080/01635580903407197.

79. Takagi, A.; Ikemura, H.; Matsuzaki, T.; Sato, M.; Nomoto, K.; Morotomi, M.; Yokokura, T. Relationship between the in Vitro Response of Dendritic Cells to Lactobacillus and Prevention of Tumorigenesis in the Mouse. J. Gastroenterol. 2008, 43 (9), 661-669. https://doi.org/10.1007/s00535-008-2212-7.

80. Gavas, S., Quazi, S. and Karpiński, T., 2021. Nanoparticles for Cancer Therapy: Current Progress and Challenges. Nanoscale Research Letters, 16(1).

81. Zackular, J. P.; Baxter, N. T.; Iverson, K. D.; Sadler, W. D.; Petrosino, J. F.; Chen, G. Y.; Schloss, P. D. The Gut Microbiome Modulates Colon Tumorigenesis. MBio 2013, 4 (6), e00692-13. https://doi.org/10.1128/mBio.00692-13.

82. Wallace, B. D.; Wang, H.; Lane, K. T.; Scott, J. E.; Orans, J.; Koo, J. S.; Venkatesh, M.; Jobin, C.; Yeh, L.-A.; Mani, S.; Redinbo, M. R. Alleviating Cancer Drug Toxicity by Inhibiting a Bacterial Enzyme. Science 2010, 330 (6005), 831-835. https://doi.org/10.1126/science.1191175.

83. Liong, M.-T. Roles of Probiotics and Prebiotics in Colon Cancer Prevention: Postulated Mechanisms and in-Vivo Evidence. Int. J. Mol. Sci. 2008, 9 (5), 854-863. https://doi.org/10.3390/ijms9050854.

84. Capurso, G.; Marignani, M.; Delle Fave, G. Probiotics and the Incidence of Colorectal Cancer: When Evidence Is Not Evident. Dig. Liver Dis. 2006, 38 Suppl 2, S277-82. https://doi.org/10.1016/S1590-8658(07)60010-3.

85. Bermúdez-Humarán, L. G.; Aubry, C.; Motta, J.-P.; Deraison, C.; Steidler, L.; Vergnolle, N.; Chatel, J.-M.; Langella, P. Engineering Lactococci and Lactobacilli for Human Health. Curr. Opin. Microbiol. 2013, 16 (3), 278-283. https://doi.org/10.1016/j.mib.2013.06.002.

86. Pol, J.; Bloy, N.; Obrist, F.; Eggermont, A.; Galon, J.; Hervé Fridman, W.; Cremer, I.; Zitvogel, L.; Kroemer, G.; Galluzzi, L. Trial Watch: DNA Vaccines for Cancer Therapy: DNA Vaccines for Cancer Therapy. Oncoimmunology 2014, 3 (1), e28185. https://doi.org/10.4161/onci.28185. 
87. Sandoval, F.; Terme, M.; Nizard, M.; Badoual, C.; Bureau, M.-F.; Freyburger, L.; Clement, O.; Marcheteau, E.; Gey, A.; Fraisse, G.; Bouguin, C.; Merillon, N.; Dransart, E.; Tran, T.; Quintin-Colonna, F.; Autret, G.; Thiebaud, M.; Suleman, M.; Riffault, S.; Wu, T.-C.; Launay, O.; Danel, C.; Taieb, J.; Richardson, J.; Zitvogel, L.; Fridman, W. H.; Johannes, L.; Tartour, E. Mucosal Imprinting of Vaccine-Induced CD8 ${ }^{+} \mathrm{T}$ Cells Is Crucial to Inhibit the Growth of Mucosal Tumors. Sci. Transl. Med. 2013, 5 (172), 172ra20. https://doi.org/10.1126/scitranslmed.3004888

88. Hamad, A.; Fragkos, K. C.; Forbes, A. A Systematic Review and Meta-Analysis of Probiotics for the Management of Radiation Induced Bowel Disease. Clin. Nutr. 2013, 32 (3), 353-360. https://doi.org/10.1016/j.clnu.2013.02.004.

89. Taper, H. S.; Roberfroid, M. B. Possible Adjuvant Cancer Therapy by Two Prebiotics-Inulin or Oligofructose. In Vivo 2005, 19, 201-204.

90. Holmes, E.; Kinross, J.; Gibson, G. R.; Burcelin, R.; Jia, W.; Pettersson, S.; Nicholson, J. K. Therapeutic Modulation of Microbiota-Host Metabolic Interactions. Sci. Transl. Med. 2012, 4 (137), 137rv6. https://doi.org/10.1126/scitranslmed.3004244.

91. Gareau, M. G.; Sherman, P. M.; Walker, W. A. Probiotics and the Gut Microbiota in Intestinal Health and Disease. Nat. Rev. Gastroenterol. Hepatol. 2010, 7 (9), 503-514. https://doi.org/10.1038/nrgastro.2010.117.

92. Hendler, R.; Zhang, Y. Probiotics in the Treatment of Colorectal Cancer. Medicines (Basel) 2018, 5 (3). https://doi.org/10.3390/medicines5030101.

93. Górska, A.; Przystupski, D.; Niemczura, M. J.; Kulbacka, J. Probiotic Bacteria: A Promising Tool in Cancer Prevention and Therapy. Curr. Microbiol. 2019, 76 (8), 939-949. https://doi.org/10.1007/s00284-019-01679-8.

94. Kinross JM, Markar S, Karthikesalingam A, Chow A, Penney N, Silk D, et al. A meta-analysis of probiotic and synbiotic use in elective surgery: does nutrition modulation of the gut microbiome improve clinical outcome? JPEN J Parenter Enteral Nutr (2013) 37(2):243-53. doi: $10.1177 / 0148607112452306$

95. Polakowski, C. B.; Kato, M.; Preti, V. B.; Schieferdecker, M. E. M.; Ligocki Campos, A. C. Impact of the Preoperative Use of Synbiotics in Colorectal Cancer Patients: A Prospective, Randomized, Double-Blind, Placebo-Controlled Study. Nutrition 2019, 58, 40-46. https://doi.org/10.1016/j.nut.2018.06.004.

96. Jiang, C.; Wang, H.; Xia, C.; Dong, Q.; Chen, E.; Qiu, Y.; Su, Y.; Xie, H.; Zeng, L.; Kuang, J.; Ao, F.; Gong, X.; Li, J.; Chen, T. A Randomized, Double-Blind, Placebo-Controlled Trial of Probiotics to Reduce the Severity of Oral Mucositis Induced by Chemoradiotherapy for Patients with Nasopharyngeal Carcinoma. Cancer 2019, 125 (7), 1081-1090. https://doi.org/10.1002/cncr.31907.

97. Quazi, S., 2021. An overview of CAR T cell mediated B cell Maturation Antigen therapy. Clinical Lymphoma Myeloma and Leukemia.

98. Altonsy, M. O.; Andrews, S. C.; Tuohy, K. M. Differential Induction of Apoptosis in Human Colonic Carcinoma Cells (Caco-2) by Atopobium, and Commensal, Probiotic and Enteropathogenic Bacteria: 
Mediation by the Mitochondrial Pathway. Int. J. Food Microbiol. 2010, 137 (2-3), 190-203. https://doi.org/10.1016/j.ijfoodmicro.2009.11.015.

99. Borowicki, A.; Michelmann, A.; Stein, K.; Scharlau, D.; Scheu, K.; Obst, U.; Glei, M. Fermented Wheat Aleurone Enriched with Probiotic Strains LGG and Bb12 Modulates Markers of Tumor Progression in Human Colon Cells. Nutr. Cancer 2010, 1-1. https://doi.org/10.1080/01635581.2010.516874.

100. Orlando, A.; Refolo, M. G.; Messa, C.; Amati, L.; Lavermicocca, P.; Guerra, V.; Russo, F. Antiproliferative and Proapoptotic Effects of Viable or Heat-KilledLactobacillus ParacaseiIMPC2.1 AndLactobacillus RhamnosusGG in HGC-27 Gastric and DLD-1 Colon Cell Lines. Nutr. Cancer 2012, 64 (7), 1103-1111. https://doi.org/10.1080/01635581.2012.717676.

101. Russo, F.; Orlando, A.; Linsalata, M.; Cavallini, A.; Messa, C. Effects OfLactobacillus Rhamnosus GGon the Cell Growth and Polyamine Metabolism in HGC-27 Human Gastric Cancer Cells. Nutr. Cancer 2007, 59 (1), 106-114. https://doi.org/10.1080/01635580701365084.

102. Quazi, S., 2021. Artificial Intelligence and Machine Learning in Precision and Genomic Medicine. Preprints.org,

103. Sadeghi-Aliabadi, H.; Mohammadi, F.; Fazeli, H.; Mirlohi, M. Effects of Lactobacillus Plantarum A7 with Probiotic Potential on Colon Cancer and Normal Cells Proliferation in Comparison with a Commercial Strain. Iran. J. Basic Med. Sci. 2014, 17 (10), 815-819.

104.Lopez, M.; Li, N.; Kataria, J.; Russell, M.; Neu, J. Live and Ultraviolet-Inactivated Lactobacillus Rhamnosus GG Decrease Flagellin-Induced Interleukin-8 Production in Caco-2 Cells. J. Nutr. 2008, 138 (11), 2264-2268. https://doi.org/10.3945/jn.108.093658.

105. Ma, E. L.; Choi, Y. J.; Choi, J.; Pothoulakis, C.; Rhee, S. H.; Im, E. The Anticancer Effect of Probiotic Bacillus Polyfermenticus on Human Colon Cancer Cells Is Mediated through ErbB2 and ErbB3 Inhibition. Int. J. Cancer 2010, 127 (4), 780-790. https://doi.org/10.1002/ijc.25011.

106. Lee, N.-K.; Son, S.-H.; Jeon, E. B.; Jung, G. H.; Lee, J.-Y.; Paik, H.-D. The Prophylactic Effect of Probiotic Bacillus Polyfermenticus KU3 against Cancer Cells. J. Funct. Foods 2015, 14, 513-518. https://doi.org/10.1016/j.jff.2015.02.019.

107. Dubey, V.; Ghosh, A. R.; Bishayee, K.; Khuda-Bukhsh, A. R. Appraisal of the Anti-Cancer Potential of Probiotic Pediococcus Pentosaceus GS4 against Colon Cancer: In Vitro and in Vivo Approaches. $J$. Funct. Foods 2016, 23, 66-79. https://doi.org/10.1016/j.jff.2016.02.032.

108. Talero, E.; Bolivar, S.; Ávila-Román, J.; Alcaide, A.; Fiorucci, S.; Motilva, V. Inhibition of Chronic Ulcerative Colitis-Associated Adenocarcinoma Development in Mice by VSL\#3. Inflamm. Bowel Dis. 2015, 21 (5), 1027-1037. https://doi.org/10.1097/mib.0000000000000346.

109. Tiptiri-Kourpeti, A.; Spyridopoulou, K.; Santarmaki, V.; Aindelis, G.; Tompoulidou, E.; Lamprianidou, E. E.; Saxami, G.; Ypsilantis, P.; Lampri, E. S.; Simopoulos, C.; Kotsianidis, I.; Galanis, A.; Kourkoutas, Y.; Dimitrellou, D.; Chlichlia, K. Lactobacillus Casei Exerts Anti-Proliferative Effects Accompanied by Apoptotic Cell Death and up-Regulation of TRAIL in Colon Carcinoma Cells. PLoS One 2016, 11 (2), e0147960. https://doi.org/10.1371/journal.pone.0147960. 
110. Saxami, G.; Karapetsas, A.; Lamprianidou, E.; Kotsianidis, I.; Chlichlia, A.; Tassou, C.; Zoumpourlis, V.; Galanis, A. Two Potential Probiotic Lactobacillus Strains Isolated from Olive Microbiota Exhibit Adhesion and Anti-Proliferative Effects in Cancer Cell Lines. J. Funct. Foods 2016, 24, 461-471. https://doi.org/10.1016/j.jff.2016.04.036.

111. Han, K. J.; Lee, N.-K.; Park, H.; Paik, H.-D. Anticancer and Anti-Inflammatory Activity of Probiotic Lactococcus Lactis NK34. J. Microbiol. Biotechnol. 2015, 25 (10), 1697-1701. https://doi.org/10.4014/jmb.1503.03033.

112. Iyer, C.; Kosters, A.; Sethi, G.; Kunnumakkara, A. B.; Aggarwal, B. B.; Versalovic, J. Probiotic Lactobacillus Reuteri Promotes TNF-Induced Apoptosis in Human Myeloid Leukemia-Derived Cells by Modulation of NF-KappaB and MAPK Signalling. Cell. Microbiol. 2008, 10 (7), 1442-1452. https://doi.org/10.1111/j.1462-5822.2008.01137.x.

113. Kim, Y.; Lee, D.; Kim, D.; Cho, J.; Yang, J.; Chung, M.; Kim, K.; Ha, N. Inhibition of Proliferation in Colon Cancer Cell Lines and Harmful Enzyme Activity of Colon Bacteria by Bifidobacterium Adolescentis SPM0212. Arch. Pharm. Res. 2008, 31 (4), 468-473. https://doi.org/10.1007/s12272-001-1180-y.

114. Cousin, F. J.; Jouan-Lanhouet, S.; Dimanche-Boitrel, M.-T.; Corcos, L.; Jan, G. Milk Fermented by Propionibacterium Freudenreichii Induces Apoptosis of HGT-1 Human Gastric Cancer Cells. PLoS One 2012, 7 (3), e31892. https://doi.org/10.1371/journal.pone.0031892.

115. Kim, Y.; Oh, S.; Yun, H. S.; Oh, S.; Kim, S. H. Cell-Bound Exopolysaccharide from Probiotic Bacteria Induces Autophagic Cell Death of Tumour Cells: Antitumour Activity of Cb-EPS via Autophagy. Lett. Appl. Microbiol. 2010, no-no. https://doi.org/10.1111/j.1472-765x.2010.02859.x.

116. Ma, E. L.; Choi, Y. J.; Choi, J.; Pothoulakis, C.; Rhee, S. H.; Im, E. The Anticancer Effect of Probiotic Bacillus Polyfermenticus on Human Colon Cancer Cells Is Mediated through ErbB2 and ErbB3 Inhibition. Int. J. Cancer 2010, 127 (4), 780-790. https://doi.org/10.1002/ijc.25011.

117. Castro, M. S.; Molina, M. A.; Di Sciullo, P.; Azpiroz, M. B.; Leocata Nieto, F.; Sterín-Speziale, N. B.; Mongini, C.; Manghi, M. A. Beneficial Activity of Enterococcus Faecalis CECT7121 in the Anti-Lymphoma Protective Response: Anti-Tumour Effects Exerted by Ent. Faecalis CECT7121. J. Appl. Microbiol. 2010, 109 (4), 1234-1243. https://doi.org/10.1111/j.1365-2672.2010.04747.x.

118. Thirabunyanon, M.; Boonprasom, P.; Niamsup, P. Probiotic Potential of Lactic Acid Bacteria Isolated from Fermented Dairy Milks on Antiproliferation of Colon Cancer Cells. Biotechnol. Lett. 2009, 31 (4), 571-576. https://doi.org/10.1007/s10529-008-9902-3.

119. Chen, Z.-F.; Ai, L.-Y.; Wang, J.-L.; Ren, L.-L.; Yu, Y.-N.; Xu, J.; Chen, H.-Y.; Yu, J.; Li, M.; Qin, W.-X.; Ma, X.; Shen, N.; Chen, Y.-X.; Hong, J.; Fang, J.-Y. Probiotics Clostridium Butyricum and Bacillus Subtilis Ameliorate Intestinal Tumorigenesis. Future Microbiol. 2015, 10 (9), 1433-1445. https://doi.org/10.2217/fmb.15.66.

120. Ghoneum, M.; Gimzewski, J. Apoptotic Effect of a Novel Kefir Product, PFT, on Multidrug-Resistant Myeloid Leukemia Cells via a Hole-Piercing Mechanism. Int. J. Oncol. 2014, 44 (3), 830-837. https://doi.org/10.3892/ijo.2014.2258. 
121. Thirabunyanon, M.; Hongwittayakorn, P. Potential Probiotic Lactic Acid Bacteria of Human Origin Induce Antiproliferation of Colon Cancer Cells via Synergic Actions in Adhesion to Cancer Cells and Short-Chain Fatty Acid Bioproduction. Appl. Biochem. Biotechnol. 2013, 169 (2), 511-525. https://doi.org/10.1007/s12010-012-9995-y.

122. Gosai, V.; Ambalam, P.; Raman, M.; Kothari, C. R.; Kothari, R. K.; Vyas, B. R. M.; Sheth, N. R. Protective Effect OfLactobacillus Rhamnosus231 against N-Methyl-N'-Nitro-N-Nitrosoguanidine in Animal Model. Gut Microbes 2011, 2 (6), 319-325. https://doi.org/10.4161/gmic. 18755.

123. Appleyard, C. B.; Cruz, M. L.; Isidro, A. A.; Arthur, J. C.; Jobin, C.; De Simone, C. Pretreatment with the Probiotic VSL\#3 Delays Transition from Inflammation to Dysplasia in a Rat Model of Colitis-Associated Cancer. Am. J. Physiol. Gastrointest. Liver Physiol. 2011, 301 (6), G1004-13. https://doi.org/10.1152/ajpgi.00167.2011.

124. Bertkova, I.; Hijova, E.; Chmelarova, A.; Mojzisova, G.; Petrasova, D.; Strojny, L.; Bomba, A.; Zitnan, R. The Effect of Probiotic Microorganisms and Bioactive Compounds on Chemically Induced Carcinogenesis in Rats. Neoplasma 2010, 57 (5), 422-428. https://doi.org/10.4149/neo_2010_05_422.

125. Kumar, A.; Singh, N. K.; Sinha, P. R. Inhibition of 1,2-Dimethylhydrazine Induced Colon Genotoxicity in Rats by the Administration of Probiotic Curd. Mol. Biol. Rep. 2010, 37 (3), 1373-1376. https://doi.org/10.1007/s11033-009-9519-1.

126. Park, E.; Jeon, G.-I.; Park, J.-S.; Paik, H.-D. A Probiotic Strain of Bacillus Polyfermenticus Reduces DMH Induced Precancerous Lesions in F344 Male Rat. Biol. Pharm. Bull. 2007, 30 (3), 569-574. https://doi.org/10.1248/bpb.30.569.

127. Walia, S.; Kamal, R.; Dhawan, D. K.; Kanwar, S. S. Chemoprevention by Probiotics during 1,2-Dimethylhydrazine-Induced Colon Carcinogenesis in Rats. Dig. Dis. Sci. 2018, 63 (4), 900-909. https://doi.org/10.1007/s10620-018-4949-Z.

128. Hu, J.; Wang, C.; Ye, L.; Yang, W.; Huang, H.; Meng, F.; Shi, S.; Ding, Z. Anti-Tumour Immune Effect of Oral Administration of Lactobacillus Plantarum to CT26 Tumourbearing Mice. J. Biosci 2015, 40, 269-279.

129. Verma, A.; Shukla, G. Synbiotic (Lactobacillus Rhamnosus+Lactobacillus Acidophilus+inulin) Attenuates Oxidative Stress and Colonic Damage in 1,2 Dimethylhydrazine Dihydrochloride-Induced Colon Carcinogenesis in Sprague-Dawley Rats: A Long-Term Study. Eur. J. Cancer Prev. 2014, 23 (6), 550-559. https://doi.org/10.1097/cej.0000000000000054.

130. Chang, J.-H.; Shim, Y. Y.; Cha, S.-K.; Reaney, M. J. T.; Chee, K. M. Effect of Lactobacillus Acidophilus KFRI342 on the Development of Chemically Induced Precancerous Growths in the Rat Colon. J. Med. Microbiol. 2012, 61 (3), 361-368. https://doi.org/10.1099/jmm.0.035154-0.

131. Gamallat, Y.; Meyiah, A.; Kuugbee, E. D.; Hago, A. M.; Chiwala, G.; Awadasseid, A.; Bamba, D.; Zhang, X.; Shang, X.; Luo, F.; Xin, Y. Lactobacillus Rhamnosus Induced Epithelial Cell Apoptosis, Ameliorates Inflammation and Prevents Colon Cancer Development in an Animal Model. Biomed. Pharmacother. 2016, 83, 536-541. https://doi.org/10.1016/j.biopha.2016.07.001.

132. Kuugbee, E. D.; Shang, X.; Gamallat, Y.; Bamba, D.; Awadasseid, A.; Suliman, M. A.; Zang, S.; Ma, 
Y.; Chiwala, G.; Xin, Y.; Shang, D. Structural Change in Microbiota by a Probiotic Cocktail Enhances the Gut Barrier and Reduces Cancer via TLR2 Signaling in a Rat Model of Colon Cancer. Dig. Dis. Sci. 2016, 61 (10), 2908-2920. https://doi.org/10.1007/s10620-016-4238-7.

133.Zhang, M.; Fan, X.; Fang, B.; Zhu, C.; Zhu, J.; Ren, F. Effects of Lactobacillus Salivarius Ren on Cancer Prevention and Intestinal Microbiota in 1, 2-Dimethylhydrazine-Induced Rat Model. $J$. Microbiol. 2015, 53 (6), 398-405. https://doi.org/10.1007/s12275-015-5046-z.

134. Lee, C. S. Gastro-Intestinal Toxicity of Chemotherapeutics in Colorectal Cancer: The Role of Inflammation. World J. Gastroenterol. 2014, 20 (14), 3751. https://doi.org/10.3748/wjg.v20.i14.3751.

135. Goldin, B. R.; Gualtieri, L. J.; Moore, R. P. The Effect of Lactobacillus GG on the Initiation and Promotion of DMH-Induced Intestinal Tumors in the Rat. Nutr. Cancer 1996, 25 (2), 197-204. https://doi.org/10.1080/01635589609514442.

136. Khailova, L.; Baird, C. H.; Rush, A. A.; Barnes, C.; Wischmeyer, P. E. Lactobacillus Rhamnosus GG Treatment Improves Intestinal Permeability and Modulates Inflammatory Response and Homeostasis of Spleen and Colon in Experimental Model of Pseudomonas Aeruginosa Pneumonia. Clin. Nutr. 2017, 36 (6), 1549-1557. https://doi.org/10.1016/j.clnu.2016.09.025

137. Wang, Y.; Liu, L.; Moore, D. J.; Shen, X.; Peek, R. M.; Acra, S. A.; Li, H.; Ren, X.; Polk, D. B.; Yan, F. An LGG-Derived Protein Promotes IgA Production through Upregulation of APRIL Expression in Intestinal Epithelial Cells. Mucosal Immunol. 2017, $10 \quad$ (2), 373-384. https://doi.org/10.1038/mi.2016.57

138. Fong, F. L. Y.; Kirjavainen, P. V.; El-Nezami, H. Immunomodulation of Lactobacillus Rhamnosus GG (LGG)-Derived Soluble Factors on Antigen-Presenting Cells of Healthy Blood Donors. Sci. Rep. 2016, 6 (1), 22845. https://doi.org/10.1038/srep22845

139. Chang, C.-W.; Liu, C.-Y.; Lee, H.-C.; Huang, Y.-H.; Li, L.-H.; Chiau, J.-S. C.; Wang, T.-E.; Chu, C.-H.; Shih, S.-C.; Tsai, T.-H.; Chen, Y.-J. Lactobacillus Casei Variety Rhamnosus Probiotic Preventively Attenuates 5-Fluorouracil/Oxaliplatin-Induced Intestinal Injury in a Syngeneic Colorectal Cancer Model. Front. Microbiol. 2018, 9, 983. https://doi.org/10.3389/fmicb.2018.00983.

140. Riehl, T. E.; Alvarado, D.; Ee, X.; Zuckerman, A.; Foster, L.; Kapoor, V.; Thotala, D.; Ciorba, M. A.; Stenson, W. F. Lactobacillus Rhamnosus GG Protects the Intestinal Epithelium from Radiation Injury through Release of Lipoteichoic Acid, Macrophage Activation and the Migration of Mesenchymal Stem Cells. Gut 2019, 68 (6), 1003-1013. https://doi.org/10.1136/gutjnl-2018-316226.

141.Zhang, W.; Zhu, Y.-H.; Yang, G.-Y.; Liu, X.; Xia, B.; Hu, X.; Su, J.-H.; Wang, J.-F. Lactobacillus Rhamnosus GG Affects Microbiota and Suppresses Autophagy in the Intestines of Pigs Challenged with Salmonella Infantis. Front. Microbiol. 2017, 8, 2705. https://doi.org/10.3389/fmicb.2017.02705.

142. Kim, J. Y.; Woo, H. J.; Kim, K. H.; Kim, E. R.; Jung, H. K. Antitumor Activity of Lactobacillus Plantarum Cytoplasm on Teratocarcinoma-Bearing Mice. J Microbiol Biotechnol 2002, 12, 998-1001.

143. Salminen S; M Deighton, ;. S. Lactic Acid Bacteria; Salminen, S., von Wright, A., Eds.; Marcel Dekker Inc: New York; USA, 1993.

144. Chiu, Y.-H.; Hsieh, Y.-J.; Liao, K.-W.; Peng, K.-C. Preferential Promotion of Apoptosis of Monocytes 
by Lactobacillus Casei Rhamnosus Soluble Factors. Clin. Nutr. 2010, 29 (1), 131-140. https://doi.org/10.1016/j.clnu.2009.07.004.

145. Amenu Delesa, D.; Jimma University, College of Natural Science, Biology Department; Jimma; Ethiopia, P.O.Box.378. Overview of Anticancer Activity of Lactic Acid Bacteria. Int. J. Adv. Res. Biol. Sci. 2017, 4 (12), 166-177. https://doi.org/10.22192/ijarbs.2017.04.12.017.

146. Nandhini, ;. B. M Palaniswamy. International Journal of Pharmacy and Pharmaceutical Sciences 5.

147. Choi, S. S.; Kim, Y.; Han, K. S.; You, S.; Oh, S.; Kim, S. H. Effects of Lactobacillus Strains on Cancer

Cell Proliferation and Oxidative Stress in Vitro. Lett. Appl. Microbiol. 2006, 42 (5), 452-458. https://doi.org/10.1111/j.1472-765x.2006.01913.x.

148. Adams, M. R.; Marteau, P. On the Safety of Lactic Acid Bacteria from Food (Letter to the Editor). Intl $J$ Fd Microbiol 1995, 27, 263-264.

149. Ishibashi, N.; Yamazaki, S. Probiotics and Safety. Am. J. Clin. Nutr. 2001, 73 (2 Suppl), 465S-470S. https://doi.org/10.1093/ajcn/73.2.465s.

150. Quazi, S., 2021. Elucidation of CRISPR-Cas9 Application in Novel Cellular Immunotherapy. Preprints.org,

151. Mäkeläinen, H.; Tahvonen, R.; Salminen, S.; Ouwehand, A. C. In Vivo Safety Assessment of Two Bifidobacterium Longum Strains. Microbiol. Immunol. 2003, 47 (12), 911-914. https://doi.org/10.1111/j.1348-0421.2003.tb03464.X.

152. Borriello, S. P.; Hammes, W. P.; Holzapfel, W.; Marteau, P.; Schrezenmeir, J.; Vaara, M.; Valtonen, V. Safety of Probiotics That Contain Lactobacilli or Bifidobacteria. Clin. Infect. Dis. 2003, 36 (6), 775780. https://doi.org/10.1086/368080.

153. Peggs, K. S.; Quezada, S. A.; Korman, A. J.; Allison, J. P. Principles and Use of Anti-CTLA4 Antibody in Human Cancer Immunotherapy. Curr. Opin. Immunol. 2006, 18 (2), 206-213. https://doi.org/10.1016/j.coi.2006.01.011.

154. Cohen, I.; Ruff, W. E.; Longbrake, E. E. Influence of Immunomodulatory Drugs on the Gut Microbiota. Transl. Res. 2021, 233, 144-161. https://doi.org/10.1016/j.trs1.2021.01.009.

155. Gopalakrishnan, V.; Helmink, B. A.; Spencer, C. N.; Reuben, A.; Wargo, J. A. The Influence of the Gut Microbiome on Cancer, Immunity, and Cancer Immunotherapy. Cancer Cell 2018, 33 (4), 570-580. https://doi.org/10.1016/j.ccell.2018.03.015.

156. Pabst, O. New Concepts in the Generation and Functions of IgA. Nat. Rev. Immunol. 2012, 12 (12), 821-832. https://doi.org/10.1038/nri3322.

157. Chen, D. S.; Mellman, I. Oncology Meets Immunology: The Cancer-Immunity Cycle. Immunity 2013, 39 (1), 1-10. https://doi.org/10.1016/j.immuni.2013.07.012.

158. Ivanov, I. I.; Atarashi, K.; Manel, N.; Brodie, E. L.; Shima, T.; Karaoz, U.; Wei, D.; Goldfarb, K. C.; Santee, C. A.; Lynch, S. V.; Tanoue, T.; Imaoka, A.; Itoh, K.; Takeda, K.; Umesaki, Y.; Honda, K.; Littman, D. R. Induction of Intestinal Th17 Cells by Segmented Filamentous Bacteria. Cell 2009, 139 (3), 485-498. https://doi.org/10.1016/j.cell.2009.09.033.

159. Atarashi, K.; Tanoue, T.; Shima, T.; Imaoka, A.; Kuwahara, T.; Momose, Y.; Cheng, G.; Yamasaki, S.; 
Saito, T.; Ohba, Y.; Taniguchi, T.; Takeda, K.; Hori, S.; Ivanov, I. I.; Umesaki, Y.; Itoh, K.; Honda, K. Induction of Colonic Regulatory T Cells by Indigenous Clostridium Species. Science 2011, 331 (6015), 337-341. https://doi.org/10.1126/science.1198469.

160. Sivan, A.; Corrales, L.; Hubert, N.; Williams, J. B.; Aquino-Michaels, K.; Earley, Z. M.; Benyamin, F. W.; Lei, Y. M.; Jabri, B.; Alegre, M.-L.; Chang, E. B.; Gajewski, T. F. Commensal Bifidobacterium Promotes Antitumor Immunity and Facilitates Anti-PD-L1 Efficacy. Science 2015, 350 (6264), 10841089. https://doi.org/10.1126/science.aac4255.

161. Vétizou, M.; Pitt, J. M.; Daillère, R.; Lepage, P.; Waldschmitt, N.; Flament, C.; Rusakiewicz, S.; Routy, B.; Roberti, M. P.; Duong, C. P. M.; Poirier-Colame, V.; Roux, A.; Becharef, S.; Formenti, S.; Golden, E.; Cording, S.; Eberl, G.; Schlitzer, A.; Ginhoux, F.; Mani, S.; Yamazaki, T.; Jacquelot, N.; Enot, D. P.; Bérard, M.; Nigou, J.; Opolon, P.; Eggermont, A.; Woerther, P.-L.; Chachaty, E.; Chaput, N.; Robert, C.; Mateus, C.; Kroemer, G.; Raoult, D.; Boneca, I. G.; Carbonnel, F.; Chamaillard, M.; Zitvogel, L. Anticancer Immunotherapy by CTLA-4 Blockade Relies on the Gut Microbiota. Science 2015, 350 (6264), 1079-1084. https://doi.org/10.1126/science.aad1329.

162. Huang, J.; Jiang, Z.; Wang, Y.; Fan, X.; Cai, J.; Yao, X.; Liu, L.; Huang, J.; He, J.; Xie, C.; Wu, Q.; Cao, Y.; Leung, E. L.-H. Modulation of Gut Microbiota to Overcome Resistance to Immune Checkpoint Blockade in Cancer Immunotherapy. Curr. Opin. Pharmacol. 2020, 54, 1-10 https://doi.org/10.1016/j.coph.2020.06.004

163. Tanoue, T.; Morita, S.; Plichta, D. R.; Skelly, A. N.; Suda, W.; Sugiura, Y.; Narushima, S.; Vlamakis, H.; Motoo, I.; Sugita, K.; Shiota, A.; Takeshita, K.; Yasuma-Mitobe, K.; Riethmacher, D.; Kaisho, T.; Norman, J. M.; Mucida, D.; Suematsu, M.; Yaguchi, T.; Bucci, V.; Inoue, T.; Kawakami, Y.; Olle, B.; Roberts, B.; Hattori, M.; Xavier, R. J.; Atarashi, K.; Honda, K. A Defined Commensal Consortium Elicits CD8 T Cells and Anti-Cancer Immunity. Nature 2019, 565 (7741), 600-605. https://doi.org/10.1038/s41586-019-0878-Z.

164. Zhu, Q.; Jin, Z.; Wu, W.; Gao, R.; Guo, B.; Gao, Z.; Yang, Y.; Qin, H. Analysis of the Intestinal Lumen Microbiota in an Animal Model of Colorectal Cancer. PLoS One 2014, 9 (6), e90849. https://doi.org/10.1371/journal.pone.0090849.

165. López, P.; Gueimonde, M.; Margolles, A.; Suárez, A. Distinct Bifidobacterium Strains Drive Different Immune Responses in Vitro. Int. J. Food Microbiol. 2010, 138 (1-2), 157-165. https://doi.org/10.1016/j.ijfoodmicro.2009.12.023.

166. Eiseman, B.; Silen, W.; Bascom, G. S.; Kauvar, A. J. Fecal Enema as an Adjunct in the Treatment of Pseudomembranous Enterocolitis. Surgery 1958, 44 (5), 854-859.

167. Grigoryan, Z.; Shen, M. J.; Twardus, S. W.; Beuttler, M. M.; Chen, L. A.; Bateman-House, A. Fecal Microbiota Transplantation: Uses, Questions, and Ethics. Med Microecol 2020, 6 (100027), 100027. https://doi.org/10.1016/j.medmic.2020.100027.

168. Neemann, K.; Eichele, D. D.; Smith, P. W.; Bociek, R.; Akhtari, M.; Freifeld, A. Fecal Microbiota Transplantation for Fulminant Clostridium Difficile Infection in an Allogeneic Stem Cell Transplant Patient. Transpl. Infect. Dis. 2012, 14 (6), E161-5. https://doi.org/10.1111/tid.12017. 
169. de Castro, C. G., Jr; Ganc, A. J.; Ganc, R. L.; Petrolli, M. S.; Hamerschlack, N. Fecal Microbiota Transplant after Hematopoietic SCT: Report of a Successful Case. Bone Marrow Transplant. 2015, 50 (1), 145. https://doi.org/10.1038/bmt.2014.212

170. Lee, M. S. L.; Ramakrishna, B.; Moss, A. C.; Gold, H. S.; Branch-Elliman, W. Successful Treatment of Fulminant Clostridioides Difficile Infection with Emergent Fecal Microbiota Transplantation in a Patient with Acute Myeloid Leukemia and Prolonged, Severe Neutropenia. Transpl. Infect. Dis. 2020, 22 (1), e13216. https://doi.org/10.1111/tid.13216.

171. Borody, T. J.; Warren, E. F.; Leis, S. M.; Surace, R.; Ashman, O.; Siarakas, S. Bacteriotherapy Using Fecal Flora: Toying with Human Motions. J. Clin. Gastroenterol. 2004, 38 (6), 475-483. https://doi.org/10.1097/01.mcg.0000128988.13808.dc.

172. Kakihana, K.; Fujioka, Y.; Suda, W.; Najima, Y.; Kuwata, G.; Sasajima, S.; Mimura, I.; Morita, H.; Sugiyama, D.; Nishikawa, H.; Hattori, M.; Hino, Y.; Ikegawa, S.; Yamamoto, K.; Toya, T.; Doki, N.; Koizumi, K.; Honda, K.; Ohashi, K. Fecal Microbiota Transplantation for Patients with Steroid-Resistant Acute Graft-versus-Host Disease of the Gut. Blood 2016, 128 (16), 2083-2088. https://doi.org/10.1182/blood-2016-05-717652.

173. Ding, X.; Yang, X.; Wang, H. Methodology, Efficacy and Safety of Fecal Microbiota Transplantation in Treating Inflammatory Bowel Disease. Medicine in Microecology 2020, 6 (100028), 100028. https://doi.org/10.1016/j.medmic.2020.100028.

174. Moayyedi, P.; Surette, M. G.; Kim, P. T.; Libertucci, J.; Wolfe, M.; Onischi, C.; Armstrong, D.; Marshall, J. K.; Kassam, Z.; Reinisch, W.; Lee, C. H. Fecal Microbiota Transplantation Induces Remission in Patients with Active Ulcerative Colitis in a Randomized Controlled Trial. Gastroenterology 2015, 149 (1), 102-109.e6. https://doi.org/10.1053/j.gastro.2015.04.001

175. Bel, S.; Elkis, Y.; Elifantz, H.; Koren, O.; Ben-Hamo, R.; Lerer-Goldshtein, T.; Rahimi, R.; Ben Horin, S.; Nyska, A.; Shpungin, S.; Nir, U. Reprogrammed and Transmissible Intestinal Microbiota Confer Diminished Susceptibility to Induced Colitis in TMF-/- Mice. Proc. Natl. Acad. Sci. U. S. A. 2014, 111 (13), 4964-4969. https://doi.org/10.1073/pnas.1319114111.

176. Cohen, N. A.; Maharshak, N. Novel Indications for Fecal Microbial Transplantation: Update and Review of the Literature. Dig. Dis. Sci. 2017, 62 (5), 1131-1145. https://doi.org/10.1007/s10620-017-4535-9.

177. Bafeta, A.; Koh, M.; Riveros, C.; Ravaud, P. Harms Reporting in Randomized Controlled Trials of Interventions Aimed at Modifying Microbiota: A Systematic Review. Ann Intern Med 2018, 169, 240247. https://doi.org/10.7326/M18-0343HuffBA.

178. Quazi, S., 2021. Telomerase Gene Therapy: A Remission Towards Cancer. Preprints.org,

179. Huff, B. A. Caveat Emptor. "Probiotics" Might Not Be What They Seem. Can. Fam. Physician 2004, 50, 583-587.

180. Amalaradjou, M. A. R.; Bhunia, A. K. Bioengineered Probiotics, a Strategic Approach to Control Enteric Infections. Bioengineered 2013, 4 (6), 379-387. https://doi.org/10.4161/bioe.23574.

181. Quazi, S., 2021. TNFR2 Antagonist and Agonist: A Potential Therapeutics in Cancer Immunotherapy. 
Preprints.org.

182. Kajikawa, A.; Masuda, K.; Katoh, M.; Igimi, S. Adjuvant Effects for Oral Immunization Provided by Recombinant Lactobacillus Casei Secreting Biologically Active Murine Interleukin-1 $\beta$ Clin Vaccine Immunol. 2010, 17, 43-48.

183. Fredriksen, L.; Kleiveland, C. R.; Hult, L. T. O.; Lea, T.; Nygaard, C. S.; Eijsink, V. G. H.; Mathiesen, G. Surface Display of N-Terminally Anchored Invasin by Lactobacillus Plantarum Activates NF-KB in Monocytes. Appl. Environ. Microbiol. 2012, $78 \quad$ (16), $\quad$ 5864-5871. https://doi.org/10.1128/AEM.01227-12.

184. Quazi, S., 2021. Vaccine in response to COVID-19: Recent developments, challenges, and a way out. Biomedical and Biotechnology Research Journal (BBRJ), 5(2), p.105.

185. Wang, Z.; Yu, Q.; Gao, J.; Yang, Q. Mucosal and Systemic Immune Responses Induced by Recombinant Lactobacillus Spp. Expressing the Hemagglutinin of the Avian Influenza Virus H5N1. Clin. Vaccine Immunol. 2012, 19 (2), 174-179. https://doi.org/10.1128/CVI.05618-11.

186. Benbouziane, B.; Ribelles, P.; Aubry, C.; Martin, R.; Kharrat, P.; Riazi, A.; Langella, P.; Bermúdez-Humarán, L. G. Development of a Stress-Inducible Controlled Expression (SICE) System in Lactococcus Lactis for the Production and Delivery of Therapeutic Molecules at Mucosal Surfaces. $J$. Biotechnol. 2013, 168 (2), 120-129. https://doi.org/10.1016/j.jbiotec.2013.04.019.

187. Bermúdez-Humarán, L. G.; Cortes-Perez, N. G.; Lefèvre, F.; Guimarães, V.; Rabot, S.; Alcocer-Gonzalez, J. M.; Gratadoux, J.-J.; Rodriguez-Padilla, C.; Tamez-Guerra, R. S.; Corthier, G.; Gruss, A.; Langella, P. A Novel Mucosal Vaccine Based on Live Lactococci Expressing E7 Antigen and IL-12 Induces Systemic and Mucosal Immune Responses and Protects Mice against Human Papillomavirus Type 16-Induced Tumors. J. Immunol. 2005, 175 (11), 7297-7302. https://doi.org/10.4049/jimmunol.175.11.7297.

188. Li, Y.; Li, X.; Liu, H.; Zhuang, S.; Yang, J.; Zhang, F. Intranasal Immunization with Recombinant Lactococci Carrying Human Papillomavirus E7 Protein and Mouse Interleukin-12 DNA Induces E7-Specific Antitumor Effects in C57BL/6 Mice. Oncol. Lett. 2014, 7 (2), 576-582. https://doi.org/10.3892/ol.2013.1743.

189. Cortes-Perez, N. G.; Bermúdez-Humarán, L. G.; Le Loir, Y.; Rodriguez-Padilla, C.; Gruss, A.; Saucedo-Cárdenas, O.; Langella, P.; Montes-de-Oca-Luna, R. Mice Immunization with Live Lactococci Displaying a Surface Anchored HPV-16 E7 Oncoprotein. FEMS Microbiol. Lett. 2003, 229 (1), 37-42. https://doi.org/10.1016/s0378-1097(03)00778-X.

190. Rangel-Colmenero, B. R.; Gomez-Gutierrez, J. G.; Villatoro-Hernández, J.; Zavala-Flores, L. M.; Quistián-Martínez, D.; Rojas-Martínez, A.; Arce-Mendoza, A. Y.; Guzmán-López, S.; Montes-de-Oca-Luna, R.; Saucedo-Cárdenas, O. Enhancement of Ad-CRT/E7-Mediated Antitumor Effect by Preimmunization with L. Lactis Expressing HPV-16 E7. Viral Immunol. 2014, 27 (9), 463467. https://doi.org/10.1089

191. Kitagawa, K.; Oda, T.; Saito, H.; Araki, A.; Gonoi, R.; Shigemura, K.; Hashii, Y.; Katayama, T.; Fujisawa, M.; Shirakawa, T. Development of Oral Cancer Vaccine Using Recombinant Bifidobacterium 
Displaying Wilms' Tumor 1 Protein. Cancer Immunol. Immunother. 2017, 66 (6), 787-798. https://doi.org/10.1007/s00262-017-1984-0.

192. Kimura, N. T.; Taniguchi, S.; Aoki, K.; Baba, T. Selective Localization and Growth of Bifidobacterium Bifidum in Mouse Tumors Following Intravenous Administration. Cancer Res. 1980, 40 (6), 20612068.

193. Yazawa, K.; Fujimori, M.; Nakamura, T.; Sasaki, T.; Amano, J.; Kano, Y.; Taniguchi, S. Bifidobacterium Longum as a Delivery System for Gene Therapy of Chemically Induced Rat Mammary Tumors. Breast Cancer Res. Treat. 2001, 66 (2), 165-170. https://doi.org/10.1023/a:1010644217648.

194. Fujimori, M.; Amano, J.; Taniguchi, S. The Genus Bifidobacterium for Cancer Gene Therapy. Curr. Opin. Drug Discov. Devel. 2002, 5 (2), 200-203.

195. Fujimori, M.; Amano, J.; Taniguchi, S. The Genus Bifidobacterium for Cancer Gene Therapy. Curr. Opin. Drug Discov. Devel. 2002, 5 (2), 200-203.

196. Sasaki, T.; Fujimori, M.; Hamaji, Y.; Hama, Y.; Ito, K.-I.; Amano, J.; Taniguchi, S. Genetically Engineered Bifidobacterium Longum for Tumor-Targeting Enzyme-Prodrug Therapy of Autochthonous Mammary Tumors in Rats. Cancer Sci. 2006, 97 (7), 649-657. https://doi.org/10.1111/j.1349-7006.2006.00221.x

197. Fujimori, M. Genetically Engineered Bifidobacterium as a Drug Delivery System for Systemic Therapy of Metastatic Breast Cancer Patients. Breast Cancer 2006, 13 (1), 27-31. https://doi.org/10.2325/jbcs.13.27

198. Wei, C.; Xun, A. Y.; Wei, X. X.; Yao, J.; Wang, J. Y.; Shi, R. Y.; Yang, G. H.; Li, Y. X.; Xu, Z. L.; Lai, M. G.; Zhang, R.; Wang, L.-S.; Zeng, W. S. Bifidobacteria Expressing Tumstatin Protein for Antitumor Therapy in Tumor-Bearing Mice. Technol. Cancer Res. Treat. 2016, 15 (3), 498-508. https://doi.org/10.1177/1533034615581977.

199. Fu, G.-F.; Li, X.; Hou, Y.-Y.; Fan, Y.-R.; Liu, W.-H.; Xu, G.-X. Bifidobacterium Longum as an Oral Delivery System of Endostatin for Gene Therapy on Solid Liver Cancer. Cancer Gene Ther. 2005, 12 (2), 133-140. https://doi.org/10.1038/sj.cgt.7700758.

200. Wang, C.; Ma, Y.; Hu, Q.; Xie, T.; Wu, J.; Zeng, F.; Song, F. Bifidobacterial Recombinant Thymidine Kinase-Ganciclovir Gene Therapy System Induces FasL and TNFR2 Mediated Antitumor Apoptosis in Solid Tumors. BMC Cancer 2016, 16 (1), 545. https://doi.org/10.1186/s12885-016-2608-3.

201. Yi, C.; Huang, Y.; Guo, Z.-Y.; Wang, S.-R. Antitumor Effect of Cytosine Deaminase/5-Fluorocytosine Suicide Gene Therapy System Mediated by Bifidobacterium Infantis on Melanoma. Acta Pharmacol. Sin. 2005, 26 (5), 629-634. https://doi.org/10.1111/j.1745-7254.2005.00094.x.

202. Del Carmen, S.; de Moreno de LeBlanc, A.; Levit, R.; Azevedo, V.; Langella, P.; Bermúdez-Humarán, L. G.; LeBlanc, J. G. Anti-Cancer Effect of Lactic Acid Bacteria Expressing Antioxidant Enzymes or IL-10 in a Colorectal Cancer Mouse Model. Int. Immunopharmacol. 2017, 42, 122-129. https://doi.org/10.1016/j.intimp.2016.11.017.

203.Li, W.; Li, C.-B. Effect of Oral Lactococcus Lactis Containing Endostatin on 1, 2-Dimethylhydrazine-Induced Colon Tumor in Rats. World J. Gastroenterol. 2005, 11 (46), 7242-7247. 
https://doi.org/10.3748/wjg.v11.i46.7242. 